\title{
Traffic Analysis of Specific Motorways with Different Usage Characteristics in Hungary with the Method of Section Control
}

\author{
Zs. Sándor ${ }^{1, *}$ Á. Monostori² \\ ${ }^{1}$ KTI Institute for Transport Sciences Non-profit Ltd. \\ 1119 Budapest, Than Károly u. 3-5., Hungary \\ 2 Glowbyte Consulting \\ 20004 Minsk, vulica Klary Cetkin 51, Belarus \\ *E-mail: zsolt.sandor1@gmail.com
}

Abstract: This article presents the result of the large-scale average speed analysis made in Hungary at two motorways in 12 different sections. During the analysis speeds of normal and reduced operations were analysed. This is the first section control analysis in Hungary which is based on individual measurement and real traffic data. Data from the enforcement system of the road use right were used and these data were provided by the Hungarian National Toll Payment Service Plc. Results have shown that the majority of the drivers do not obey the speed limits, which has huge risk on traffic safety.

Keywords: section control; speed enforcement; control method; speed control

\section{Introduction}

Unfavourable traffic factors can be influenced with exploration of causes of road traffic accidents and safety can be significantly improved with implementation of root cause related measures.

Significant part of the road traffic accidents are originated in inappropriately selected speeds or specifically to speeding. Only in 2018 31.4\% (5254 PCS) of the total accidents are caused by the inappropriate speed (exceeding the maximum speed limit - absolute speeding - or selecting a speed that is inappropriate for the actual road conditions - relative speeding) [1]. 
The main intention of the authors was to elaborate and establish an efficient measure possibility, which aims to decrease the number of road accidents connected to speeding. By the help of the measure, accidents caused by the improper speed choice may be avoided. These kinds of accidents are the most significant on motorways (due to the higher speed and traffic), so the probability of speeding should be mitigated on those roads [6], [16]. Section control - as a control method can be implemented most efficiently on such infrastructure therefore the authors have focused on the motorways.

The structure of the paper is the following: $2^{\text {nd }}$ chapter contains some professional background of the speed enforcement. $3^{\text {rd }}$ chapter gives a short summary of the international results of the section control enforcement measurement. The applied analysis methodology is presented in the $4^{\text {th }}$ chapter, while the results can be found in the $5^{\text {th }}$ chapter. Chapter 6 contains information about the outlook of the measurement and a short summary is closing the paper in chapter 7. Detail diagrams of the analysed sections can be found in the $8^{\text {th }}$ chapter.

\section{Background of speed enforcement possibilities and user acceptance}

Drivers' behaviour (speed choice) can be influenced by soft and hard measures in order to choose appropriate speed fitting to the traffic rules and taking environmental circumstances into consideration like actual traffic, weather, visibility, road condition, etc.

Soft measures are awareness and information campaigns that open the drivers' eyes to the potential dangers, moreover non-sanctioning local speed measurement devices with actual speed information displays also belong to this category. Hard (or enforcing) measures are those procedures where the authorities enforce the rules by sanctions (penalties, fines, demerit points, etc.). Hard measure can be an infrastructure based (even physical) decelerate solution, but in the paper it means a forced behaviour by the law without physical barriers.

From the viewpoint of enforcement, the most common solution is the local speed enforcement / spot measurement procedure in Hungary. During this process, the measuring device is locally detecting the actual speed of the passing vehicle in front of the equipment at the observation point. When the speed of the vehicle is higher than the limit on the road for the given vehicle category, the driver or the owner / operator of the vehicle will be sanctioned according to the degree of speeding (fine, penalty point).

A significant number of road users criticized the spot measurement procedure, moreover international research have shown that their effects on traffic safety are 
lower than expected. Users are accommodating to the measurements in the given environment [2, 3, 4]. In order to avoid the potential sanctions, drivers decelerate in the vicinity of the measurement spots and they accelerate again when they leave the control area. It is also proved that the effect of local speed enforcement on traffic safety is less in rural than in urban environment (based on the number of accidents) [5]. Automated solutions that do not require human / police supervision can be more efficient, but they have only local effects.

Within the law-abiding majority of the drivers accept a more effective and fairer measurement and sanctioning system where the basis of the sanction is not the momentaneous speed, but based on the average speed measured along the route. Section control (with other phases: section cameras, average speed control, etc.) can be a solution for this, which has been implemented in several countries with success. The system calculates the speed of the vehicle between two well-defined locations based on the distance of the measurement spots and the elapsed time between the detections. When the vehicle that passes through the section has exceeded the speed limit based on the calculation, it may be subject to a penalty procedure for speeding. For reasons of legal certainty, both the measuring devices and the applied calculation method and implementation have to be officially validated.

The aim of the system is to enforce and decrease the number of speeders by hard measures (by sanctioning). With this effect the homogeneity of speed values is improving (speed differences between the vehicles are decreasing), thus the traffic safety and the stability of the traffic flow are increasing [6]. Further positive effects are the lower emission of noise and pollutants by the lower and more homogenous speeds - number of accelerations and decelerations are reducing, and at lower speeds the $\mathrm{CO} 2$ and other emissions are also reduced [7].

The advantage of the system is the fact that it is closed (on sections where entry and exit is not possible) and the users cannot avoid it, thus $100 \%$ of the passing traffic can be detected and controlled. Because of the fact that all vehicle is under control, the social acceptance of the system is much higher like other (momentaneous / spot / local) speed enforcement solutions.

Section control measurement systems are mainly installed on special sections of the motorway network or other closed road sections, since those locations are appropriate for the operations of the system. Speeding is most common on these sections and accident risk is also higher on these roads because of the higher speeds. Reducing speeding is the common interest of all stakeholders of the road transport, as a significant proportion of accidents are due to this cause - in 2018 almost 1/3 of the accidents happened due to inappropriate speed choice [1].

Significant proportion of the accidents on the motorway network can be related to human mistakes (more than $40 \%$ of all accidents) and within this cause the main 
cause is the inappropriate speed choice. Speeding is a key factor in case of the fatal accidents on motorways. In 2017 and 2018 more than 50\% of the fatal accidents were triggered by this phenomenon. Further details about speeding can be seen on Figure 1 (number of accidents is indicated on the main axis, while proportion of the outcome is indicated on the secondary axis) [1].

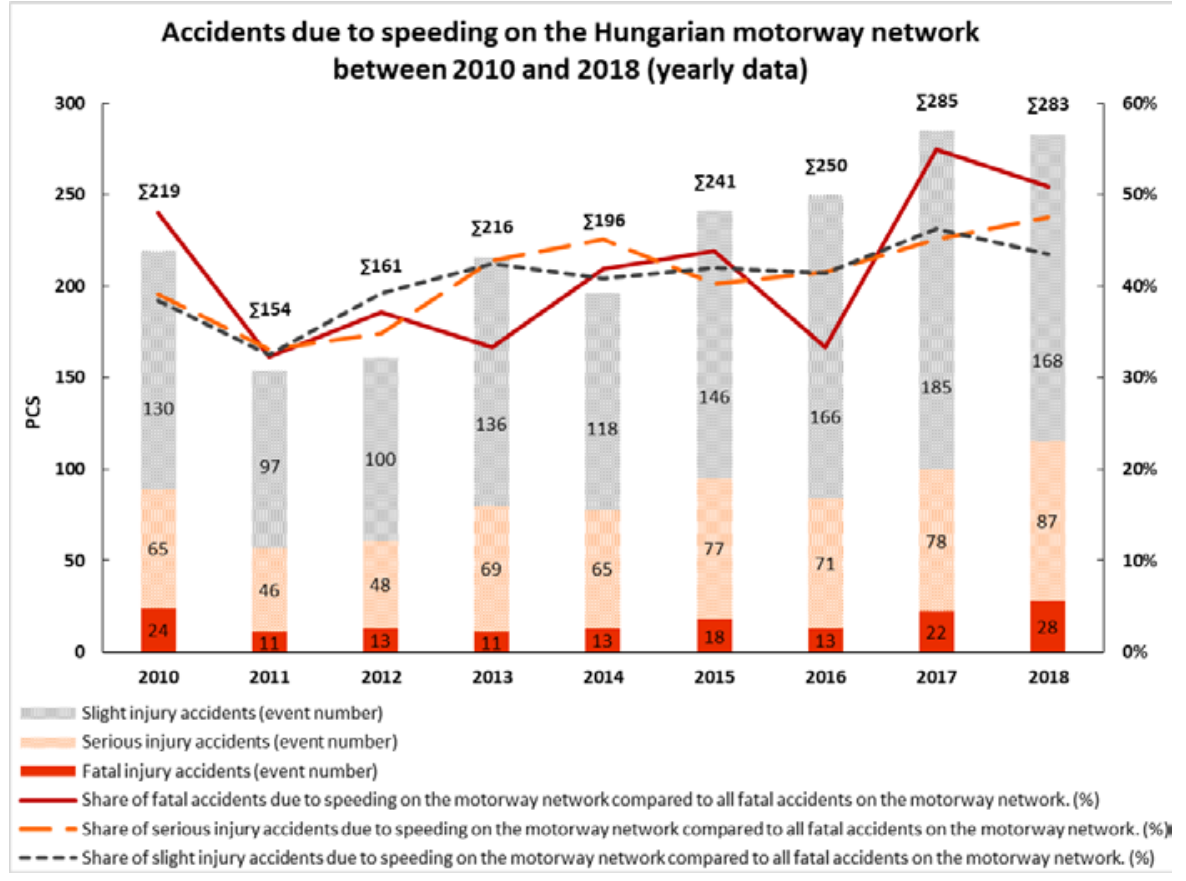

Figure 1. Speeding caused accidents on the Hungarian motorway network between 2010 and 2018

In this article the analysis of section control made for the Hungarian motorway network is presented. Necessary input data were provided by the National Toll Payment Service (NTPS) Plc. Data came from the toll enforcement infrastructure and gathered by the business intelligence system operated by the NTPS. Within the examination, traffic analysis were conducted which were based on the average speed measurement. The use and the analysis of data were carried out in accordance with the applicable data protection and GDPR regulations.

The current Hungarian regulations contain the subject of the average speed enforcement system (GKM Decree 18/2008. (IV.30.)) but the legal framework for its application is missing, thus these kinds of traffic control and sanctioning measures 
are not applied. In Hungary the Police operates a complex speed control system (called VÉDA) which has the capability of this function that could be completed by the system of NTPS in terms of measurement and supplying data.

First proposals for the use of the average speed enforcement system in the Hungarian literature appeared already in 2004 in connection with the speed analysis of M1 and M7 motorways. Proportion of speeders was significant even at that time [8].

\section{International outlook}

First section control measurement system was implemented in the Netherlands, on a $3 \mathrm{~km}$ long three-lane section of the A-2 motorway between Utrecht and Amsterdam at the end of 1997 as a trial solution. The implementation served multiple purposes by sanctioning of the speeders: initial goals were to decrease the number of accidents by $25 \%$, improve the flow of traffic and decrease the congestion by $40 \%$. Further IT goal was to fully automatize the sanctioning procedure and decrease the processing time [10]. The system was capable of identifying the passing vehicle, and detect traffic offences accordingly to its category (e.g. passenger car, truck, bus, etc.).

Based on the positive effects (which were more significant than the goals - see Table 1.), from 2002 new section control measurement systems were implemented in the upcoming years in the Netherlands and this method was used at several spots with traffic control solutions as well. The aim of the implementations varied from site to site: while in some places the main objective was to increase traffic safety, in others (urban environment) it was intended to mitigate the negative environmental impact of transport. By 2014 such enforcement systems had been installed on 11 sections [7]. After the Dutch initiation several European countries have introduced the section control measurements on rural and urban roads [11, 12, 13, 7]. Table 1 contains the results of different implementations [2, 14, 15]. In Europe, the latest implementation of section control measurement was in Serbia in 2018. The system calculates the average speed for the given section, when the vehicle arrives at the tollgate. 
Table 1. Effects of the introduction of section control measurements, international summary

\begin{tabular}{|c|c|c|c|}
\hline Location and features & \begin{tabular}{|l|} 
Max. speed \\
$(\mathbf{k m} / \mathbf{h})$
\end{tabular} & Traffic safety effects & Traffic and environmental effects \\
\hline $\begin{array}{l}\text { Austria A22 tunnel in Vienna } \\
\text { daily traffic is over } 90.000 \text { vehicle } \\
\text { 3-4 lanes sections } \\
\text { It has been operating since } 2003 \text {. } \\
\text { [2], [12] }\end{array}$ & $\begin{array}{l}\text { cars: } 80 \\
\text { trucks: } 60\end{array}$ & $\begin{array}{l}\text { Accidents with personal injuries decreased by } \\
33.3 \% \text {. } \\
\text { Fatal and serious accidents reduced by 50\% } \\
\text { Minor injuries reduced by 32\% } \\
\text { * Note, that accident risk of the tunnel is lower than } \\
\text { the other parts of the road. }\end{array}$ & $\begin{array}{l}\text { Average speeds were decreased: } \\
\text { Cars in daylight by } 10 \mathrm{~km} / \mathrm{h} \text {, night by } 20 \mathrm{~km} / \mathrm{h} \\
\text { Trucks in daylight by } 15 \mathrm{~km} / \mathrm{h} \text {, night by } 20 \\
\mathrm{~km} / \mathrm{h} \\
\text { Further environmental effects in the filed of } \\
\text { emission: CO: }-15 \% \text {, NOx: }-39 \% \text {. }\end{array}$ \\
\hline $\begin{array}{l}\text { Italy, on the whole } 2900 \mathrm{~km} \text { long } \\
\text { network } \\
\text { It has been operating since } 2005 \text { on the } \\
2-3 \text { lanes sections. Length of the } \\
\text { sections are between } 2 \text { and } 40 \mathrm{~km} . \\
\text { Enforcement is operating on app. } 200 \\
\text { sections. [2], [13] }\end{array}$ & $\begin{array}{l}\text { generally } \\
130\end{array}$ & $\begin{array}{l}\text { Fatal accidents decreased by 51\% } \\
\text { Serious accidents decreased by 35\% } \\
\text { Risk of an accident per one million travelled } \\
\text { kilometres reduced by } 22 \% .\end{array}$ & $\begin{array}{l}\text { Average speeds decreased: by } 15 \% \text { which } \\
\text { meant } 16 \mathrm{~km} / \mathrm{h} \text { decrease, maximum values } \\
\text { decreased by } 25 \% \text { which is a further } 23 \mathrm{~km} / \mathrm{h} \\
\text { decrease. Recent results have show a further } \\
\text { reduction of average speeds by } 9 \mathrm{~km} / \mathrm{h} \text {. } \\
\text { The decrease in speed is more noticeable in } \\
\text { lower traffic periods than in rush hours. }\end{array}$ \\
\hline $\begin{array}{l}\text { Italy - Motorway A1 Naples-Milan } \\
(80 \mathrm{~km}) \\
{[2],[13]}\end{array}$ & 130 & $\begin{array}{l}\text { Accidents with personal injuries decreased by 31\%. } \\
\text { Severe injuries reduced by } 56 \% \text { and minor } \\
\text { injuries by } \sim 27 \% \text {. }\end{array}$ & no data \\
\hline $\begin{array}{l}\text { Italy - Naples } \\
{[2],[13]}\end{array}$ & 80 & $\begin{array}{l}\text { Accidents with personal injuries decreased by app. } \\
40 \% \text {. }\end{array}$ & $\begin{array}{l}\text { Average speeds decreased from } 80.8 \mathrm{~km} / \mathrm{h} \text { to } \\
71.7 \mathrm{~km} / \mathrm{h} \text { and the standard deviation of average } \\
\text { speeds decreased by } 33 \% \text { from } 18.1 \mathrm{~km} / \mathrm{h} \text { to } \\
12.1 \mathrm{~km} / \mathrm{h} \text {. }\end{array}$ \\
\hline $\begin{array}{l}\text { Norway - Trial operation on three } \\
\text { locations from 2009, sections with } \\
\text { different length. Gradually expansion } \\
\text { for } 14 \text { locations - } 8 \text { tunnels. [11]. [15] }\end{array}$ & 80 & $\begin{array}{l}\text { Generally the number of accidents decreased by } \\
23 \% \text {, fatal and serious injury accidents decreased } \\
\text { by } 49-54 \% \text { (depending on the locations, in case of } \\
\text { tunnels the reduction is more significant). }\end{array}$ & $\begin{array}{l}\text { Average speeds decreased by } 2.7-10.2 \mathrm{~km} / \mathrm{h}, \\
\text { moreover in the cross-sections the speed was } \\
\text { further reduced by an average of } 3.3 \mathrm{~km} / \mathrm{h} \text {. } \\
\text { Rate of decline was higher where average } \\
\text { speeds were higher before the implementation. }\end{array}$ \\
\hline
\end{tabular}




\begin{tabular}{|c|c|c|c|}
\hline Location and features & \begin{tabular}{|l|} 
Max. speed \\
$(\mathbf{k m} / \mathbf{h})$
\end{tabular} & Traffic safety effects & Traffic and environmental effects \\
\hline \begin{tabular}{|l} 
England - 7 different sections, first \\
installed in 1999. [2], [13], [14]
\end{tabular} & $\begin{array}{l}\text { different, } \\
\text { between } 50 \\
\text { and } 95\end{array}$ & $\begin{array}{l}\text { Significant reduction in fatal accidents, } 100 \% \\
\text { reduction on several sections. Reduction of serious } \\
\text { and minor accidents is at least } 40 \% \text {. }\end{array}$ & $\begin{array}{l}\text { Results have shown significant decrease in the } \\
\text { average speeds. At } 50 \mathrm{~km} / \mathrm{h} \text { speed limit the } \\
\text { reduction was } 10 \mathrm{~km} / \mathrm{h} \text {. } \\
\text { The v85 speed decreased by } 15 \mathrm{~km} / \mathrm{h} \text {. }\end{array}$ \\
\hline $\begin{array}{l}\text { Scotland - Strathclyde A77 } \\
51.5 \text { km long section [2], [13], [14] }\end{array}$ & $\begin{array}{l}\text { national } \\
\text { general } \\
\text { speed limit }\end{array}$ & $\begin{array}{l}\text { Overall, the number of accidents decreased by } \\
25 \% \text {. } \\
\text { fatalities decreased by } 50 \% \text {, } \\
\text { Serious injury accidents decreased by } 41 \% \text {, } \\
\text { Slight injury accidents decreased by } 19 \% \text {. }\end{array}$ & $\begin{array}{l}\text { Number of speeders decreased by } 90 \% \text { on dual } \\
\text { carriageway sections and by } 80 \% \text { on single } \\
\text { carriageway sections. }\end{array}$ \\
\hline $\begin{array}{l}\text { Netherlands - A2 motorway, trial } \\
\text { period 1997 } \\
\text { [2], [7], [10] }\end{array}$ & 120 & $\begin{array}{l}\text { The proportion of offenders dropped significantly } \\
\text { from } 6 \% \text { to } 0.6 \% \text {, which is } 90 \% \text { decrease. } \\
\text { The number of accidents and congestion has } \\
\text { decreased as traffic flow has become smoother. }\end{array}$ & $\begin{array}{l}\text { Average speed decreased from } 116 \mathrm{~km} / \mathrm{h} \text { to } \\
106 \mathrm{~km} / \mathrm{h} \text {. } \\
\text { Two thirds of the offenders were trucks. } \\
\text { Its social acceptance is more favourable than } \\
\text { the local speed control measures. }\end{array}$ \\
\hline $\begin{array}{l}\text { Netherlands - } 5 \text { motorway sections } \\
\text { with a limit of } 80 \mathrm{~km} / \mathrm{h} \\
\text { Speed limit was introduced in } 2002 \\
\text { and } 2005 \text {. Aim was to improve air } \\
\text { quality by reducing emissions. The } \\
\text { measure was reviewed several times } \\
\text { and the introduced restriction was } \\
\text { cancelled on several locations until } \\
\text { 2014, but speed enforcement is still in } \\
\text { operation for the actual speed limits. [ } \\
\text { [10], [13], [15] }\end{array}$ & 80 & $\begin{array}{l}\text { The calculated value of accidents decreased at each } \\
\text { sections - Nilsson model was used to estimate this } \\
\text { value and the decrease was between } 5 \text { and } 20 \% \text {. }\end{array}$ & $\begin{array}{l}\text { Average speeds were decreased in all } \\
\text { circumstances. It was between } 4-9 \mathrm{~km} / \mathrm{h} \text {. } \\
\text { Air quality has improved significantly in the } \\
\text { affected sections: } \\
\text { airborne dust emissions: - 8-9\%, NOX: - 20- } \\
\text { 32\%, noise pollution: }-1-2.5 \mathrm{dBA} \text {. }\end{array}$ \\
\hline
\end{tabular}


Based on the results of international studies made in the topic, the following experiences can be observed on the road sections with section control measures in connection of the drivers' behaviour, traffic safety effects and environmental changes [2, 14]:

- $\quad$ only a negligible proportion of vehicles - less than $1 \%$ - drive faster than the speed limit;

- $\quad$ in case of road works thanks to the section control measurements number of faults is 11 times lower compared to conventional spot speed enforcement acts;

- $\quad$ the method is particularly effective in reducing extreme speeding;

- $\quad$ number of fatal and serious injury accidents are significantly decreasing (rate of decrease is $40-65 \%$ ) but there are sections where this value is $100 \%$;

- $\quad$ the benefit-cost ratio (BCR) is high in all cases, it is typically above 5 and 7, but in Australia it is between 10 and 16;

- due to the decreasing average speed and the more homogenous traffic composition the fuel consumption is reducing, thus traffic-related emission is also reducing (CO: - 15\%; $\mathrm{NO}_{\mathrm{X}}$ : - 5-25\%; $\mathrm{PM}_{10}$ : - 6-35\%; $\left.\mathrm{CO}_{2}:-5 \%\right)$.

Based on the results, it can be seen that significant improvement can be achieved in mitigating the negative externalities (pollution, accidents, etc.) related to road transport by the use of section control measurements.

\section{Method for the identification of possible effects}

Data collected by the gantries - operated by the NTPS - were used for the analysis. All data are stored for statistical purposes in the business intelligence system of the NTPS. Conditions of the study were determined based on literature research and analytical experience, taking the stored data in the data warehouse system into consideration.

Section control measurement requires that the inspection section should be closed, thus all entering and exiting vehicles can be detected. The speciality of the Hungarian fixed installation toll enforcement infrastructure is that they do not cover $100 \%$ of the entire motorway network. Sections between the entries and exits are not covered with gantries in $100 \%$. Thus, it is not possible to monitor all traffic because the network cannot be considered as a closed section due to the installation density of the gantries - there are entries and exits on the sections that are covered by the gantries. Accordingly, those vehicles were involved in the analysis that passed under each gantry (at least two) during their journey on a given road. Moreover, it was not possible to identify that part of the traffic which stopped temporally at a rest area. 
Therefore, some vehicles were statistically excluded from the study (due to the low average speed they were deleted and their data were not taken into consideration), or some vehicles reduced their average speed by gaining time at the rest areas.

The exact locations of the gantries are known. Equipment installed on the portals record the vehicle parameters of the passing vehicle (number plate, country code, dimensions, etc.) and the exact time (GPS-based) of the passing. Based on the time differences of the passing under two gantries in view of the distance of the gantries the average speed of a given vehicle can be calculated accurately. Recorded data about each passing are stored in the audited data warehouse system of NTPS. Data was collected from this data warehouse during the analysis. The system automatically classifies the passing vehicle according to their dimensions based on the laser scanning and post data refinement. Passenger vehicles are in the $\mathrm{D} 1{ }^{1}$ vehicle category. In order to determine the traffic affected by the section control measurement (SC traffic), passes of D1 vehicle category were ranked in chronological order. Those data were used for the analysis where the given vehicle was detected sequentially at the start and end point of the predefined section and during the analysis period it was not detected on other sections. With this condition it was able to exclude the traffic, which may have left the motorway between the beginning and the end of the predefined section. Based on the recorded time of passes the average speed of a given vehicle was calculated in view of the length of the section (meter) and the detection time elapsed between the two gantries (second).

There are motorway entries and exits as well as rest areas between the crosssections on the examination sections used for the analysis, thus there may have been such cases where the vehicle was detected by the system at two spots in sequentially, but presumably, it left the network or stopped for a longer period between the detections. The average speed of these passes can be determined but they reach 0 $\mathrm{km} / \mathrm{h}$ depending on the elapsed time. These passes would distort the proportions thus the analysis was done by speed data that are over $60 \mathrm{~km} / \mathrm{h}$ on a given section (only those passes were included, where a given licence plate was appeared on two adjacent gantries within the time which is necessary to complete the section at least $60 \mathrm{~km} / \mathrm{h}$ ).

Gantries operated by NTPS apply local speed measurement for the recording of the passes vehicles (information is used for video technical purposes only - picture recording technology requires speed information for the exposure). The configuration and the location of the installed equipment are optimized for the picture recordings (devices are not located over the middle of lanes). This speed data

\footnotetext{
${ }^{1}$ Motorcycles and passenger cars for up to 7 persons with a maximum authorized mass of 3.5 tons and their trailers.
} 
may differ significantly from the actual speed (the data are provided by the sick laser $^{2}$ instead of the radar), and the measurement itself is not validated. By changing the location of radar devices, they are also capable of measuring speed data by reverifying and re-validating devices. However, during the section control enforcement, it is not necessary to measure local speed of the passing vehicles, but the fact, that the $\mathrm{km}$ sections on the motorways may deviate from the real distance has to be taken into consideration. Thus, the tolerance of the measurement and the sanctioning has to be determined in regard to this phenomenon.

Currently applied legal authorization does not allow that the NTPS uses the toll enforcement related data for other enforcement activities, like handing over of the data of speeders to the sanctioning authority.

The analysis was performed with privacy considerations in mind. License plates were Hash encoded, which ensures that one-way encoding does not decrypt the original data. Thus during the analysis, the original license plates were not known, so all data were deprived of their personal data.

Data recorded by the gantries were compared with data recorded by handheld GPS devices in order to determine the accuracy. Based on the results it can be stated that the differences between the data recorded by different technologies are less than $0.5 \%$, thus data from the infrastructure of the NTPS are considered as valid data for the analysis.

\section{Steps of the complex analysis:}

1. Investigation of the location of toll enforcement infrastructure (gantries) on the motorway network.

2. Selection of sections covered by the toll enforcement infrastructure.

3. Traffic analysis of the sections and determination of free travel times ${ }^{3}\left(t_{\min }\right)$ $>$ is there any restriction on the section which hinders the continuous progress with $130 \mathrm{~km} / \mathrm{h}$ ? If there is any, it was taken into consideration in the calculation of free travel times (these restrictions are typically locally applied due to the design of the infrastructure - e.g. tunnel, valley bridge, smaller curve radius, etc.).

4. Selection of the time period to be investigated.

5. Identification of temporary restrictions on the selected section in the analysis period.

\footnotetext{
2 Two or three dimensional (1 or 2 headed) profile scanner for vehicle categorization (dimension measuring and indirect axis counting) and triggering purposes

${ }^{3}$ the time required to complete a given section with the maximum permitted speed
} 
6. Examination of the availability of data provided by the toll enforcement infrastructure in the given period (Did maintenance works or road diversions hinder the continuous data collection?).

7. Filtering of distortion data (e.g. data during the changeover of daylight saving time, data from incorrect detection, etc.).

M5 and M6 motorways were chosen for the analysis and this article contains their results. Figure 2. illustrates their location in Hungary with the location of the gantries and the base details of selected sections. The latter illustrates the details of normal operational conditions. Detail information about the exact locations are presented in Table 2. and 4.

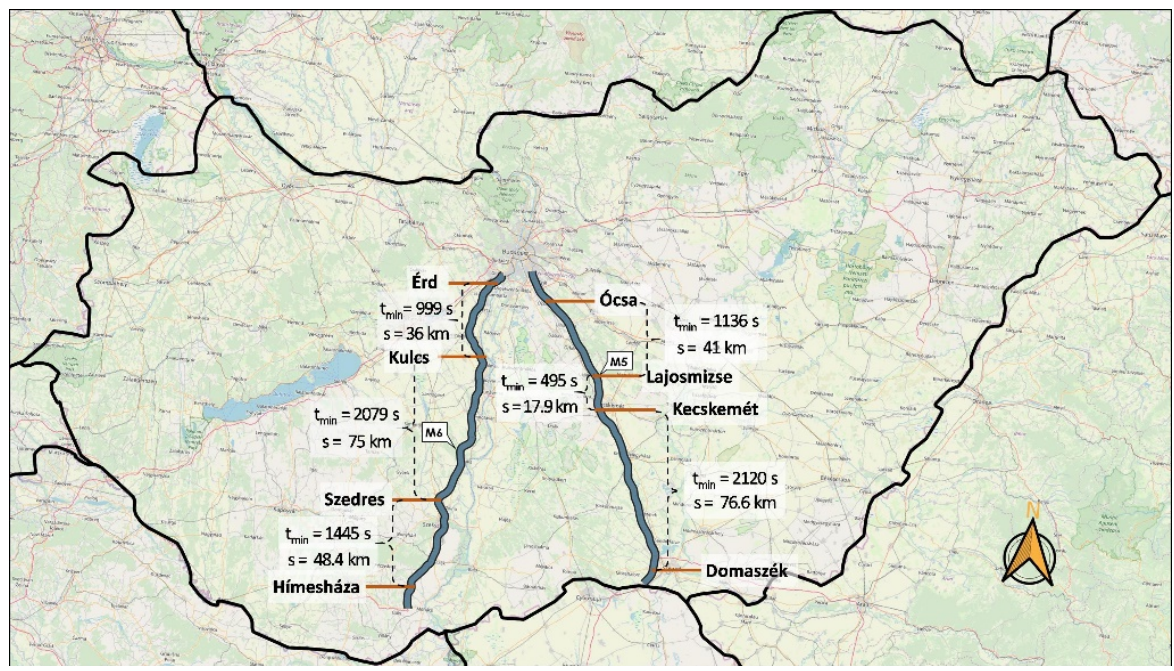

Figure 2. $\quad$ Location of the selected motorways in Hungary

Reason of the choice:

- The analysis methodology can be well demonstrated on selected motorway sections.

- $\quad$ The two motorways have different traffic parameters: M5 has high, while M6 has low traffic.

- These motorways were not affected by extensive maintenance and construction works as well as diversion interventions. Local works with diversions were applied, but they could be easily handled during the analysis.

- $\quad$ It is possible to study the effects of permanent speed restrictions on the M6 motorway (design characteristics like tunnels and valley bridges). 
- $\quad$ M5 motorway is not affected by permanent speed restrictions.

In 2018 on the M5 motorway there were maintenance works on several sections, thus it was possible to study the effects of road works and the compliance rate of speed limits connected to the works.

\section{Results}

\subsection{Results for motorway M6}

NTPS has eight gantries on M6, four pieces on each carriageway. Based on the information of the motorway management companies all permanent speed restrictions were collected that hinder the continuous flow with $130 \mathrm{~km} / \mathrm{h}$ on the carriageways between the gantries. By the help of these data, minimum travel time $\left(t_{\min }\right)$ were determined for each sections, which is required for the law-abiding behaviour if vehicle is moving at the maximum permitted speed.

The study is based on the complete data of 2018 for D1 category vehicles. Based on the information provided by the motorway management companies, only one maintenance work was in the indicated period that may have influenced the results and lasted at least 168 hours. These data were filtered out.

Traffic characteristics were determined for all sections affected by section control measurement. For this calculation all detections at the end of the sections were taken into consideration (asymmetry can be found in the traffic on the two carriageways because the traffic volume decreases the further we are away from Budapest, moreover the control system cannot be considered as a closed system from the viewpoint of the traffic - there are entries and exits between the gantries). Number of individual licence plates that appeared at the beginning and at the end of the sections were counted (SC traffic). This traffic was proportioned to the whole traffic counted at the end of the sections (SC proportion). See Table 2 for details. Based on the results it can be seen that approximately $60 \%$ of the total traffic appears on two sequential gantries on the M6 motorway.

Table 3. contains the cross-sectional travel time and speed details of the sections. The table contains the static parameters of the sections and the results of traffic analysis. Due to the permanent speed restrictions, if the vehicle is travelling with the maximum permitted speed the average speed of the southern section of the motorway is 121 or $122 \mathrm{~km} / \mathrm{h}$, depending on the carriageway. In order to provide the commensurability of the different sections, these lower values were scaled to 130 $\mathrm{km} / \mathrm{h}$, thus sections can be compared. Detailed velocity and speed distribution diagrams for each section are included in Chapter 8.1. 
Table 2. Data of M6 motorway for the section control calculations about 2018.

\begin{tabular}{|c|c|c|c|c|c|c|c|}
\hline \multicolumn{4}{|c|}{ right carriageway } & \multicolumn{4}{|c|}{ traffic data of the sections } \\
\hline gantry & location & \begin{tabular}{|l} 
number of \\
recorded \\
passes (for \\
all vehicle \\
category) \\
\end{tabular} & \begin{tabular}{|l} 
number of \\
recorded \\
passes (D1 \\
vehicle \\
category) \\
\end{tabular} & section & $\begin{array}{l}\text { SC traffic } \\
\text { in D1 } \\
\text { vehicle } \\
\text { category }\end{array}$ & $\begin{array}{l}\text { SC proportion } \\
\text { compared to } \\
\text { the traffic of } \\
\text { the section* }\end{array}$ & $\begin{array}{l}\text { SC } \\
\text { average** }\end{array}$ \\
\hline Érd & $22+293$ & 4983254 & 3637530 & & & & \\
\hline Hímesháza & $181+854$ & 1307842 & 838715 & & & & \\
\hline total & & 11468017 & 8123992 & $\begin{array}{l}\text { total and } \\
\text { average }\end{array}$ & 3378314 & $72.4 \%$ & $75.3 \%$ \\
\hline \multicolumn{4}{|c|}{ left carriageway } & \multicolumn{4}{|c|}{ traffic data of the sections } \\
\hline gantry & location & $\begin{array}{l}\text { number of } \\
\text { recorded } \\
\text { passes (for } \\
\text { all vehicle } \\
\text { category) } \\
\end{array}$ & \begin{tabular}{|l|} 
number of \\
recorded \\
passes (D1 \\
vehicle \\
category) \\
\end{tabular} & section & $\begin{array}{l}\text { SC traffic } \\
\text { in D1 } \\
\text { vehicle } \\
\text { category }\end{array}$ & $\begin{array}{l}\text { SC proportion } \\
\text { compared to } \\
\text { the traffic of } \\
\text { the section* }\end{array}$ & $\begin{array}{l}\text { SC } \\
\text { average** }\end{array}$ \\
\hline Hímesháza & $181+828$ & 1319057 & 828329 & & & & \\
\hline Érd & $22+318$ & 4825156 & 3514729 & & & & \\
\hline \multicolumn{2}{|l|}{ total } & 11429466 & 8051404 & $\begin{array}{l}\text { total and } \\
\text { average }\end{array}$ & 3462177 & $45.7 \%$ & $47.9 \%$ \\
\hline \multicolumn{4}{|c|}{ aggregated data } & \multicolumn{4}{|c|}{ aggregated data of the sections } \\
\hline direction & section & $\begin{array}{l}\text { number of } \\
\text { recorded } \\
\text { passes (for } \\
\text { all vehicle } \\
\text { category) } \\
\end{array}$ & $\begin{array}{l}\text { number of } \\
\text { recorded } \\
\text { passes (D1 } \\
\text { vehicle } \\
\text { category) } \\
\end{array}$ & section & $\begin{array}{l}\text { SC traffic } \\
\text { in D1 } \\
\text { vehicle } \\
\text { category }\end{array}$ & $\begin{array}{l}\text { SC average of } \\
\text { the sections } \\
\text { per directions }\end{array}$ & $\begin{array}{l}\text { global SC } \\
\text { average }\end{array}$ \\
\hline right & $\begin{array}{l}22+293- \\
181+854\end{array}$ & 11468017 & 8123992 & $\begin{array}{l}\text { Érd- } \\
\text { Hímesháza }\end{array}$ & 3378314 & $75.3 \%$ & \\
\hline left & $\begin{array}{l}181+828- \\
22+318\end{array}$ & 11429466 & 8051404 & $\begin{array}{l}\text { Hímesháza- } \\
\text { Érd }\end{array}$ & 3462177 & $47.9 \%$ & \\
\hline total & & 22897483 & 16175396 & $\begin{array}{l}\text { total and } \\
\text { average }\end{array}$ & 6840491 & $\begin{array}{l}\text { average of } \\
\text { sections: } \\
61.6 \% \\
\end{array}$ & $58.4 \%$ \\
\hline
\end{tabular}

* proportioning was made to the number of the detected passes at the end of the given section during the calculation

** all SC traffic / all passes at the end of the sections 
Results are showing that a significant part of the drivers do not obey the $130 \mathrm{~km} / \mathrm{h}$ speed limit on the motorway sections (38-50\% depending on the sections). Moreover, the 85 percentile values are much higher than the speed limit.

The analysis examined whether the days of the week had any significant impact on speeding, but there was no significant difference between workdays and public holidays.

Table 3. Main results of the traffic analysis of M6 motorway.

\begin{tabular}{|c|c|c|c|c|c|c|}
\hline \multirow{2}{*}{ parameters sections } & \multicolumn{3}{|c|}{ right carriageway } & \multicolumn{3}{|c|}{ left carriageway } \\
\hline & $\begin{array}{c}\text { northern } \\
\text { section } \\
22+293- \\
58+365 \\
\end{array}$ & $\begin{array}{c}\text { middle } \\
\text { section } \\
58+365- \\
133+455 \\
\end{array}$ & $\begin{array}{c}\text { southern } \\
\text { section } \\
133+455- \\
181+854 \\
\end{array}$ & $\begin{array}{c}\text { southern } \\
\text { section } \\
181+828- \\
133+405 \\
\end{array}$ & $\begin{array}{c}\text { middle } \\
\text { section } \\
133+405- \\
58-340 \\
\end{array}$ & $\begin{array}{c}\text { northern } \\
\text { section } \\
58-340- \\
22+318 \\
\end{array}$ \\
\hline$s$ - length $(\mathrm{km})$ & 36.072 & 75.09 & 48.399 & 48.423 & 75.065 & 36.022 \\
\hline $\mathrm{t}_{\min }(\mathrm{sec})$ & 999 & 2079 & 1445 & 1440 & 2079 & 998 \\
\hline$\overline{\overline{v_{t_{\min }}}}(\mathrm{km} / \mathrm{h})$ & 130 & 130 & 121 & 122 & 130 & 130 \\
\hline $\begin{array}{l}\text { number of analysed } \\
\text { days (PCS) }\end{array}$ & 365 & 352 & 352 & 365 & 365 & 365 \\
\hline $\begin{array}{l}\text { number of total SC } \\
\text { passes (PCS) }\end{array}$ & 1881822 & 949512 & 546980 & 557211 & 996244 & 1908722 \\
\hline $\begin{array}{l}\text { measured average } \\
\text { speed }(\mathrm{km} / \mathrm{h})\end{array}$ & 123.4 & 125.1 & 118.9 & 116.6 & 125.2 & 124.2 \\
\hline standard deviation & 19.8 & 21.6 & 20.32 & 20.44 & 20.69 & 19.72 \\
\hline median $(\mathrm{km} / \mathrm{h})$ & 126 & 129 & 122 & 120 & 129 & 127 \\
\hline $\mathrm{V}_{85}{ }^{4}(\mathrm{~km} / \mathrm{h})$ & 140 & 143 & $136^{*}$ & $143^{*}$ & 142 & 140 \\
\hline $\begin{array}{l}\text { proportion of the } \\
\text { traffic over } 130 \\
\mathrm{~km} / \mathrm{h} \text { (based on the } \\
\text { distribution } \\
\text { function) }\end{array}$ & $38.4 \%$ & $45.2 \%$ & $50.2 \% *$ & $42 \% *$ & $44.8 \%$ & $40.2 \%$ \\
\hline $\begin{array}{l}\text { end of the } 99.99 \% \\
\text { range }(\mathrm{km} / \mathrm{h}) * *\end{array}$ & 210 & 220 & $230^{*}$ & $225^{*}$ & 220 & 210 \\
\hline $\begin{array}{l}\text { Frequency and } \\
\text { distribution fig. no. }\end{array}$ & M6-1 & M6-3 & M6-5 & M6-7 & M6-9 & M6-11 \\
\hline $\begin{array}{l}\text { Frequency and } \\
\text { distribution fig. no. for } \\
\text { traffic over } 130 \mathrm{~km} / \mathrm{h}\end{array}$ & M6-2 & M6-4 & M6-6 & M6-8 & M6-10 & M6-12 \\
\hline
\end{tabular}

* Calculated by corrected speed values, in order to ensure the commensurability of the different sections

** Frequency and distribution charts are scaled until this value, because over this value the undistorted representation of the graph is not accomplishable.

${ }^{4}$ The 85 percentile speed $\left(\mathrm{V}_{85}\right)$ is that speed at which $85 \%$ of the vehicles are travelling at or below this speed at the spot and time of the measurement. From traffic safety and traffic flow viewpoint it would be desirable that the $\mathrm{v}_{85}$ speed and the locally applied speed limit are close to each other. 


\subsection{Results for motorway M5}

NTPS has eight gantries on M5, four pieces on each carriageway. Based on the information of the motorway management company there is no permanent speed restriction on the motorway, thus vehicles can travel by $130 \mathrm{~km} / \mathrm{h}$ between the gantries on the whole motorway. It is hindered only by maintenance works.

The study is based on the complete data of 2018 for D1 category vehicles, similar to the M6 motorway in the previous chapter. There were several maintenance works with different speed restrictions during the summer of 2018. These works lasted at least 168 hours and they permanently hindered the $130 \mathrm{~km} / \mathrm{h}$ progress of the vehicles. Thus, it was possible to examine the effects of restrictions on the speed of traffic flow. Table 4. contains the recorded traffic data. Calculation method can be found in the previous section.

\subsection{Effects of temporal traffic restrictions}

During the summer of 2018, maintenance works with speed restrictions were carried out over several kilometres on the northern and middle sections of M5 motorway (Ócsa-Lajosmizse and Lajosmizse-Kecskemét). Based on the information provided by the concessionaire company (carriageway, exact time, speed restriction, start and end of the restricted section) minimum travel times ( $t^{\prime}$ min $)$ were determined for each carriageway that are necessary to complete the sections taking the speed restrictions into consideration during the works. Based on the distance and the minimum times, the average speeds $\left(\overline{v_{t^{\prime} \min }}\right)$ could be calculated. Effects of the speed restrictions on traffic could be determined based on the data of passing vehicles and the minimum travel times.

There were several overlapping and intermittent restrictions on the sections. Due to space limitation only some results related to significant and large-scale works are presented in this chapter (Table 5.). The table contains the static parameters of the sections and the main effects of speed restrictions on the flow of traffic. Detailed velocity and speed distribution charts for each section are included in Chapter 8.2.

Based on the results it can be stated that on a motorway section, which is affected by road works only a low proportion of the drivers obey the limits (only a few \%). On longer sections with 60 or $80 \mathrm{~km} / \mathrm{h}$ speed limit only a few percent of drivers obey the limits. In addition, due to the specific nature of the measurement, it is also possible that drivers may have driven faster that the limit on these sections which were affected by works, but on other sections they drove at lower speed and overall, their average speeds were lower.

On the right carriageway between Lajosmizse-Kecskemét only 2-4\% of the drivers obeyed the speed limits during the period affected by the speed limits due to the road 
works. The average speed of the remaining vehicles were higher than the calculated $\overline{v_{t \prime} \min }$ speed value.

Table 4. Data of M5 motorway for the section control calculations about 2018.

\begin{tabular}{|c|c|c|c|c|c|c|c|}
\hline \multicolumn{4}{|c|}{ right carriageway } & \multicolumn{4}{|c|}{ traffic data of the sections } \\
\hline gantry & location & $\begin{array}{l}\text { number of } \\
\text { recorded } \\
\text { passes (for } \\
\text { all vehicle } \\
\text { category) } \\
\end{array}$ & \begin{tabular}{|l|} 
number of \\
recorded \\
passes (D1 \\
vehicle \\
category) \\
\end{tabular} & section & $\begin{array}{l}\text { SC traffic in } \\
\text { D1 vehicle } \\
\text { category }\end{array}$ & \begin{tabular}{|l|} 
SC \\
proportion \\
compared to \\
the traffic of \\
the section* \\
\end{tabular} & $\begin{array}{l}\text { SC } \\
\text { average } \\
* *\end{array}$ \\
\hline Ócsa & $29+252$ & 11100444 & 6815257 & & & & \\
\hline Domaszék & $164+708$ & 1808183 & 1247657 & & & & \\
\hline összesen & & 28128353 & 17109679 & $\begin{array}{l}\text { összesen és } \\
\text { átlag }\end{array}$ & 8136841 & $78 \%$ & $79 \%$ \\
\hline \multicolumn{4}{|c|}{ left carriageway } & \multicolumn{4}{|c|}{ traffic data of the sections } \\
\hline gantry & location & $\begin{array}{l}\text { number of } \\
\text { recorded } \\
\text { passes (for } \\
\text { all vehicle } \\
\text { category) } \\
\end{array}$ & $\begin{array}{l}\text { number of } \\
\text { recorded } \\
\text { passes (D1 } \\
\text { vehicle } \\
\text { category) } \\
\end{array}$ & section & $\begin{array}{l}\text { SC traffic in } \\
\text { D1 vehicle } \\
\text { category }\end{array}$ & \begin{tabular}{|l} 
SC \\
proportion \\
compared to \\
the traffic of \\
the section* \\
\end{tabular} & $\begin{array}{l}\text { SC } \\
\text { average } \\
* *\end{array}$ \\
\hline Domaszék & $164+734$ & 1704112 & 1154952 & & & & \\
\hline Ócsa & $29+278$ & 10462896 & 6517386 & & & & \\
\hline total & & 25794686 & 15726383 & $\begin{array}{l}\text { total and } \\
\text { average }\end{array}$ & 7214543 & $47.5 \%$ & $49.5 \%$ \\
\hline \multicolumn{4}{|c|}{ aggregated data } & \multicolumn{4}{|c|}{ aggregated data of the sections } \\
\hline direction & section & $\begin{array}{l}\text { number of } \\
\text { recorded } \\
\text { passes (for } \\
\text { all vehicle } \\
\text { category) }\end{array}$ & \begin{tabular}{|l|} 
number of \\
recorded \\
passes (D1 \\
vehicle \\
category) \\
\end{tabular} & section & $\begin{array}{l}\text { SC traffic in } \\
\text { D1 vehicle } \\
\text { category }\end{array}$ & $\begin{array}{l}\text { SC average } \\
\text { of the } \\
\text { sections per } \\
\text { directions }\end{array}$ & $\begin{array}{l}\text { global } \\
\text { SC } \\
\text { average }\end{array}$ \\
\hline right & $\begin{array}{l}29+252- \\
164+708 \\
\end{array}$ & 28128353 & 17109679 & $\begin{array}{l}\text { Ócsa- } \\
\text { Domaszék }\end{array}$ & 8136841 & $79 \%$ & \\
\hline left & $\begin{array}{l}164+734- \\
29+278\end{array}$ & 25794686 & 15726383 & $\begin{array}{l}\text { Domaszék- } \\
\text { Ócsa }\end{array}$ & 7214543 & $49.5 \%$ & \\
\hline total & & 53923039 & 32836062 & $\begin{array}{l}\text { total and } \\
\text { average }\end{array}$ & 15351384 & $\begin{array}{l}\text { average of } \\
\text { sections: } 64.3 \%\end{array}$ & $61.7 \%$ \\
\hline
\end{tabular}

* proportioning was made to the number of the detected passes at the end of the given section during the calculation $* *$ all SC traffic / all passes at the end of the sections

*** traffic connected to motorway M43 was not analysed 
Table 5. Maintenance works on M5 motorway and their details and effects on the flow of traffic in 2018

\begin{tabular}{|c|c|c|c|c|c|c|c|c|}
\hline \multirow[b]{2}{*}{ section } & \multicolumn{4}{|c|}{ right carriageway } & \multicolumn{4}{|c|}{ left carriageway } \\
\hline & $\begin{array}{c}\text { Ócsa- } \\
\text { Lajosmizse } \\
29+252- \\
70+264 \\
\end{array}$ & \multicolumn{3}{|c|}{$\begin{array}{l}\text { Lajosmizse-Kecskemét } \\
70+264-88+147\end{array}$} & $\begin{array}{c}\text { Lajosmizse- } \\
\text { Ócsa } \\
70+238- \\
29+278 \\
\end{array}$ & \multicolumn{3}{|c|}{$\begin{array}{c}\text { Kecskemét-Lajosmizse } \\
88+173-70+238\end{array}$} \\
\hline $\mathrm{t}_{\min }(\mathrm{sec})$ & 1128 & \multicolumn{3}{|c|}{495} & 1134 & \multicolumn{3}{|c|}{497} \\
\hline $\begin{array}{l}\text { length of the } \\
\text { section }(\mathrm{km})\end{array}$ & 41.012 & \multicolumn{3}{|c|}{17.883} & 40.96 & \multicolumn{3}{|c|}{17.935} \\
\hline $\begin{array}{l}\text { speed restrictions } \\
(\mathrm{km} / \mathrm{h})\end{array}$ & 60 & $\begin{array}{c}80 \text { and } \\
60\end{array}$ & 60 & 60 & 60 & \multicolumn{2}{|c|}{60 and 100} & $\begin{array}{c}60 \text { and } \\
80\end{array}$ \\
\hline $\begin{array}{l}\text { total length of } \\
\text { restriction }(\mathrm{km})\end{array}$ & 8.35 & 8.9 & 8.65 & 7.4 & 8.3 & 6.8 & 5.5 & 4.8 \\
\hline $\begin{array}{l}\text { t' }{ }_{\text {min }} \text { in case of } \\
\text { restriction }(\mathrm{sec})\end{array}$ & 1398 & 771 & 775 & 734 & 1402 & 665 & 623 & 631 \\
\hline$\overline{\overline{v_{t^{\prime} \min }}}(\mathrm{km} / \mathrm{h})$ & 105.6 & 83.5 & 83.1 & 87.7 & 105.2 & 97.1 & 103.6 & 102.3 \\
\hline $\begin{array}{l}\text { period (month } \\
\text { and day) }\end{array}$ & $\begin{array}{l}06.02- \\
06.07\end{array}$ & $\begin{array}{l}05.08- \\
05.13\end{array}$ & $\begin{array}{l}07.04- \\
07.10\end{array}$ & $\begin{array}{l}06.17- \\
07.01\end{array}$ & $06.03-06.07$ & $\begin{array}{l}07.04- \\
07.10\end{array}$ & $\begin{array}{c}05.19- \\
06.13\end{array}$ & $\begin{array}{l}07.22- \\
07.30\end{array}$ \\
\hline $\begin{array}{l}\text { number of } \\
\text { analysed days } \\
\text { (PCS) }\end{array}$ & 6 & 6 & 7 & 15 & 5 & 7 & 26 & 9 \\
\hline $\begin{array}{l}\text { number of total } \\
\text { SC passes (PCS) }\end{array}$ & 57478 & 56858 & $\begin{array}{l}100 \\
023\end{array}$ & $\begin{array}{l}164 \\
798\end{array}$ & 40527 & 75078 & $\begin{array}{l}268 \\
595\end{array}$ & $\begin{array}{l}123 \\
115\end{array}$ \\
\hline $\begin{array}{l}\text { measured average } \\
\text { speed }(\mathrm{km} / \mathrm{h})\end{array}$ & 109.9 & 107.2 & 105.9 & 109.5 & 113.7 & 110.7 & 108.2 & 107 \\
\hline $\begin{array}{l}\text { standard } \\
\text { deviation }\end{array}$ & 18.4 & 11.6 & 11.4 & 11.7 & 11.2 & 18.5 & 18.3 & 20.5 \\
\hline median $(\mathrm{km} / \mathrm{h})$ & 114 & 107 & 106 & 109 & 114 & 116 & 113 & 113 \\
\hline $\mathrm{V}_{85}(\mathrm{~km} / \mathrm{h})$ & 125 & 118 & 117 & 121 & 121 & 122 & 124 & 121 \\
\hline $\begin{array}{l}\text { proportion of the } \\
\text { traffic over } \overline{v_{t^{\prime} \min }} \\
\text { (based on the } \\
\text { distribution } \\
\text { function) }\end{array}$ & $67.6 \%$ & $97.1 \%$ & $98.1 \%$ & $96.1 \%$ & $64.6 \%$ & $87.2 \%$ & $77.4 \%$ & $74.6 \%$ \\
\hline $\begin{array}{l}\text { end of the } \\
99.99 \% \text { range } \\
(\mathrm{km} / \mathrm{h}) *\end{array}$ & 170 & 170 & 155 & 165 & 160 & 160 & 165 & 160 \\
\hline $\begin{array}{l}\text { Frequency and } \\
\text { distribution fig. no. }\end{array}$ & M5-1 & M5-3 & M5-5 & M5-7 & M5-9 & M5-11 & M5-13 & M5-15 \\
\hline $\begin{array}{l}\text { Frequency and } \\
\text { distribution fig. } \\
\text { no. for traffic over } \\
130 \mathrm{~km} / \mathrm{h}\end{array}$ & M5-2 & M5-4 & M5-6 & M5-8 & M5-10 & M5-12 & M5-14 & M5-16 \\
\hline
\end{tabular}

* Frequency and distribution charts are scaled until this value, because over this value the undistorted representation of the graph is not accomplishable. 


\section{Outlook}

The implementation of new speed enforcement systems provides new opportunities (e.g. like business) to the road infrastructure operators and the IT system operators. These are outlined below as potential opportunities that can be exploited by the specific actors of the transport institutions:

- The traffic safety of road works area can be increased by the use of these enforcement systems, where the speeding is a significant accident cause. This requires that NTPS be subject to the $50^{\text {th }}$ Act of 2013, which is about the Electronic Information Security of State and Local Government Bodies.

- Supplying of data about the average speeds to the sanctioning authority could be a portfolio expansion for the NTPS. Currently available infrastructure can ensure this possibility.

- Coverage of toll enforcement network can be enlarged by the use of data collected by the sanctioning authorities by similar enforcement devices; moreover the sanctioning authorities can enlarge the data collecting coverage with the information gathered by the infrastructure of NTPS. This cooperation can establish further possibilities between the different institutes.

- Integrated traffic safety measures can be implemented by the help of section control measurement. Its acceptance is much higher than the spot speed enforcement, moreover it is also socially fairer as it sanctions a specific driving behaviour which regards to a given, longer period, not to a momentaneous act. However, without the extension of the current infrastructure, only those vehicles can be controlled which pass under at least two gantries. This is a significant part of the total traffic (60\%) but not all users.

- One possibility of the enhancement of the control depth is to integrate separate control data (mobile toll control data, spot speed control data) into the complex section control enforcement system. In order to ensure the quality requirements accurate GPS location data should be connected to the transferred stock. Locally recorded data are stored with GPS location data.

It would be possible to modify the fine and speed ranges connected to the speeding in order not only extreme speeders (vehicles over $150 \mathrm{~km} / \mathrm{h}$ ) are the subject of the fines. 


\section{Conclusion}

The implementation of section control enforcement was analysed in the paper. The study is the first Hungarian analysis, which was based on significant amount of longterm (more half-years) individualised traffic data. The study focused on the motorway network. Two motorways were investigated (M5 and M6) that had significantly different parameters in terms of traffic and temporary restrictions.

Subject of the study was to identify the behaviour of drivers (speed selection) on specific motorway sections, which were affected by road works with diversions and speed restrictions. The main question was that what proportion of the traffic obeys the speed restrictions even in normal operation conditions and in conditions affected by speed limits due to maintenance works. One of the main findings of the study is that only a small proportion (a few per cent) of the total traffic obey the temporary speed limits in case of road works or maintenance works. The compliance rate is inversely proportional to the length of the restricted sections and the currently applied speed limit. This statement is based on the traffic data of M5 motorway.

Findings [8] from 2004 are true even 15 years later. Speeding is still a common driver's behaviour and research results show similar values. The 85 percentiles remain above the maximum speed limit even now, which means that drivers find higher speeds still safe. However, fluctuations within the days of the week were not detected.

During the selection of the research topic, a dominant aspect was the fact that significant part of the accidents happened on the Hungarian motorways were due to the inappropriate choice of speed. Moreover, the seriousness of the topic has been enhanced by the local accident circumstances - several fatal and serious injury accidents happened on different motorway sections that were affected by diversions and road works. Based on the information provided by the Hungarian Public Road company, only in 2018, 83 accidents were happened in sections affected by maintenance works on motorways. Most of the accidents happen at the beginning of the diversion (road work area): drivers do not give way for each other, or do not consider the warning signals and they hit the work area, or even between the workers. In 2018 distracted drivers hit the road work accessories or infrastructure elements (signs, cones, etc.) or maintenance vehicles 37 times. 9 times these drivers crashed into the Truck Mounted Attenuator. Most of the events were property damage only (PDO) accidents, but serious and fatal accidents also occurred.

Improved road safety is the common interest of the society. Based on the results, it can be stated that by soft measures, by increasing driver's compliance with traffic rules it results only a low efficiency, because most people do not take speed limits into account. Only hard (sanctioning) measure can force the drivers to obey the rules and regulation with high effectiveness. 


\section{Appendix. Frequency and speed distribution figures}

\subsection{Supplementary data of M6 motorway sections}

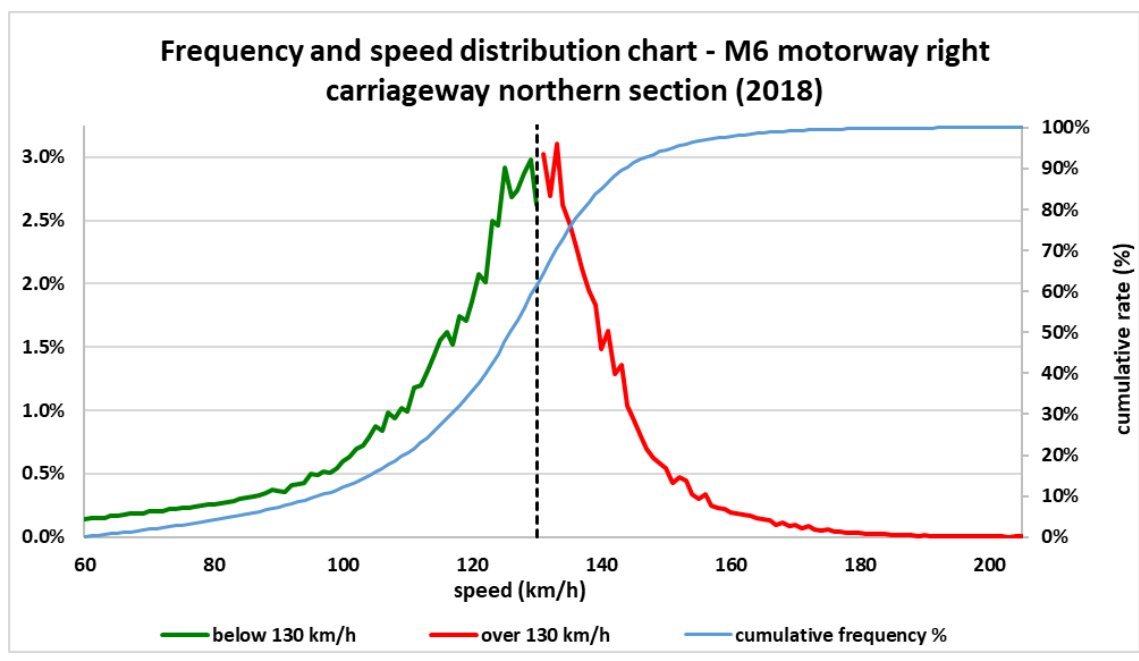

Figure M6-1. Frequency and speed distribution chart - M6 motorway right carriageway northern section (2018)

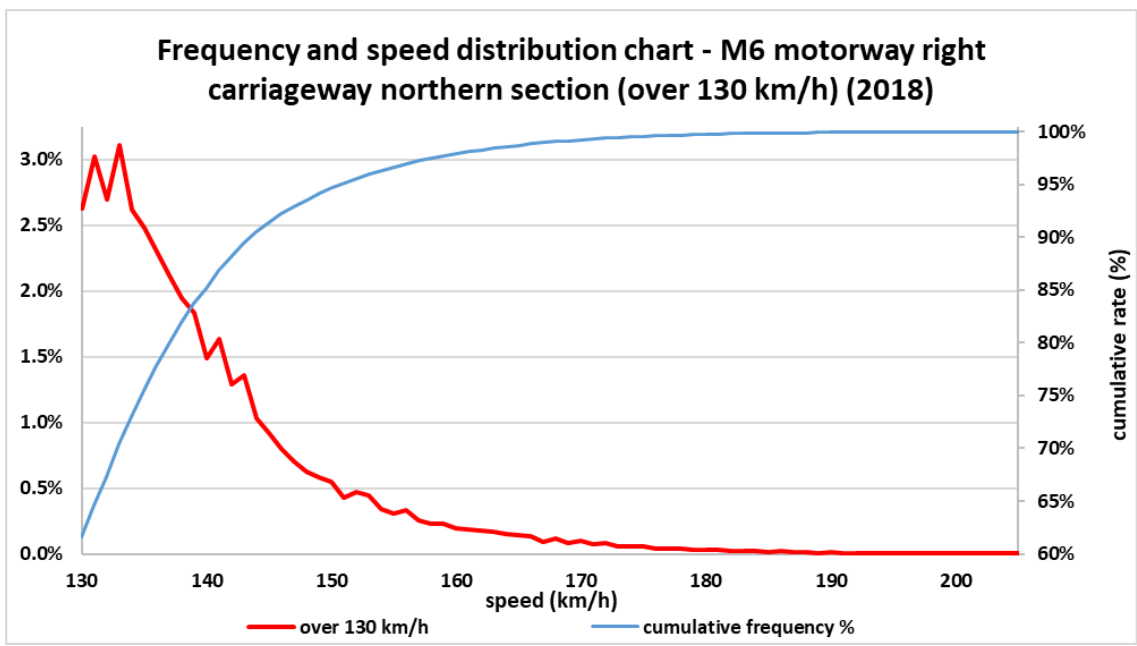

Figure M6-2. Frequency and speed distribution chart - M6 motorway right carriageway northern section (over $130 \mathrm{~km} / \mathrm{h}$ ) (2018) 
Zs. Sándor and Á. Monostori. - Acta Technica Jaurinensis, Vol. 13, No. 3, pp. 211-245, 2020

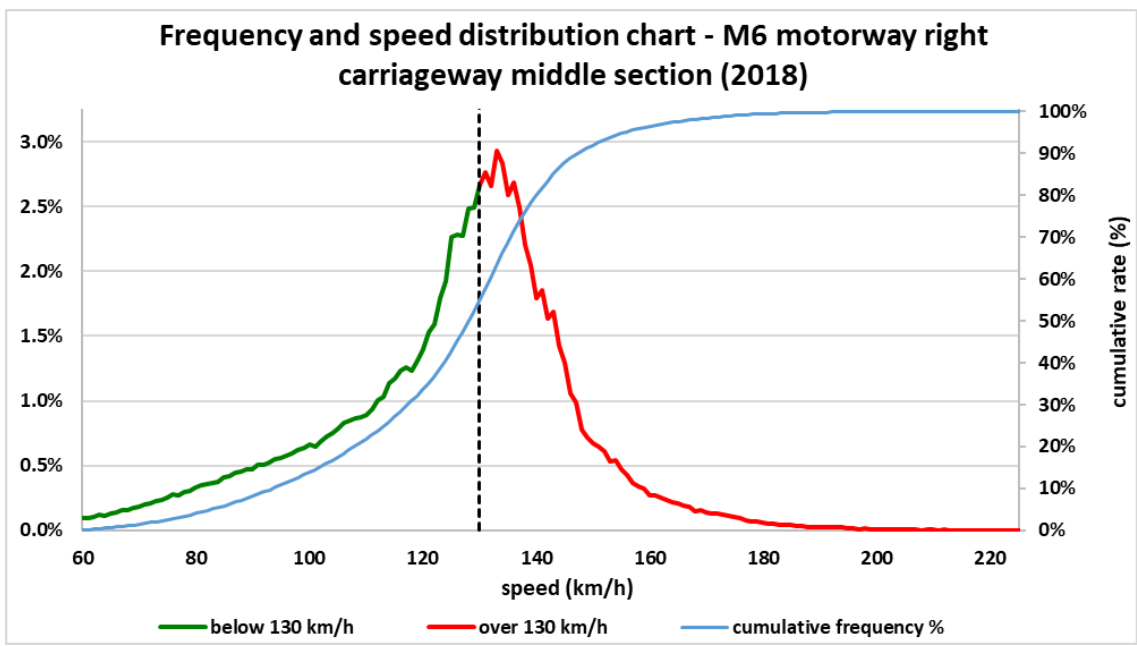

Figure M6-3. Frequency and speed distribution chart - M6 motorway right carriageway middle section (2018)

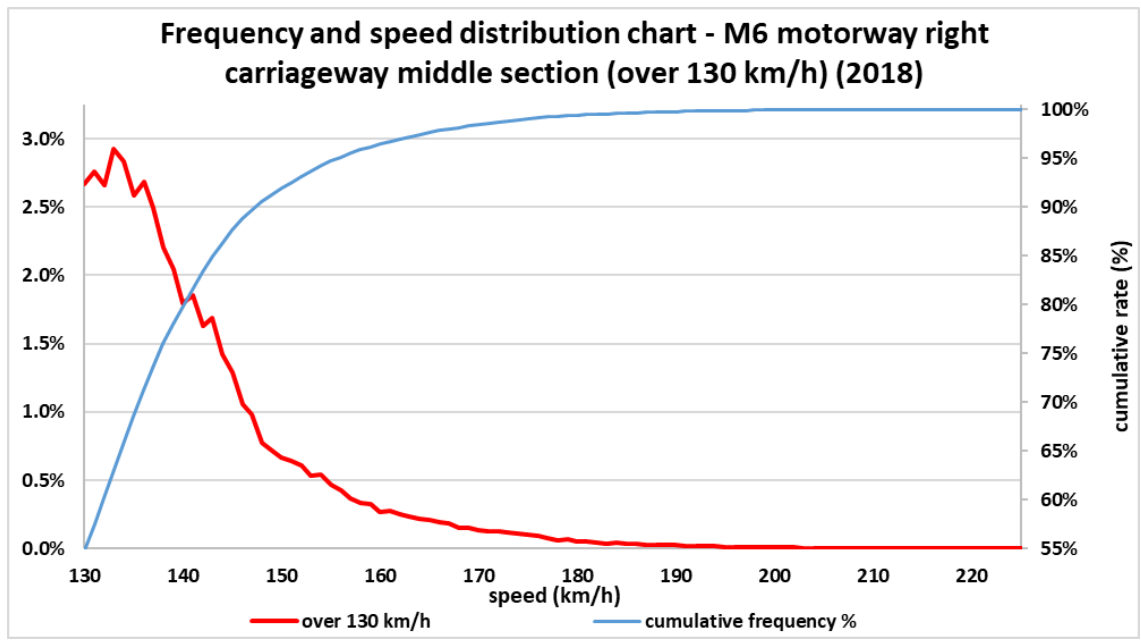

Figure M6-4. Frequency and speed distribution chart - M6 motorway right carriageway middle section (over $130 \mathrm{~km} / \mathrm{h}$ ) (2018) 
Zs. Sándor and Á. Monostori. - Acta Technica Jaurinensis, Vol. 13, No. 3, pp. 211-245, 2020

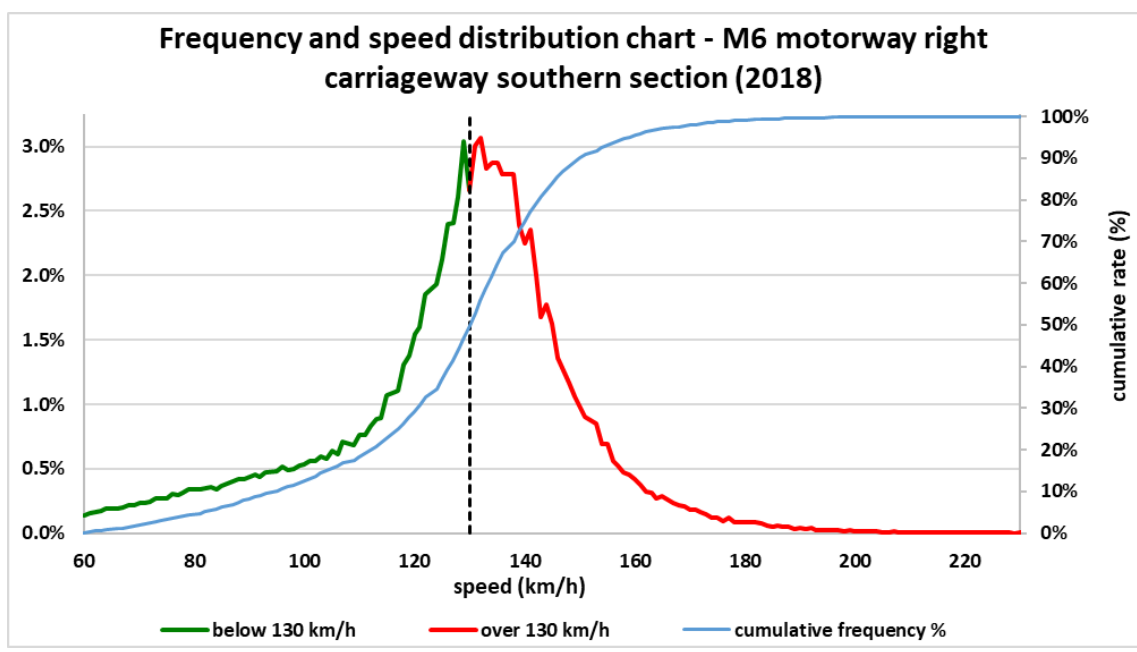

Figure M6-5. Frequency and speed distribution chart - M6 motorway right carriageway southern section (2018)

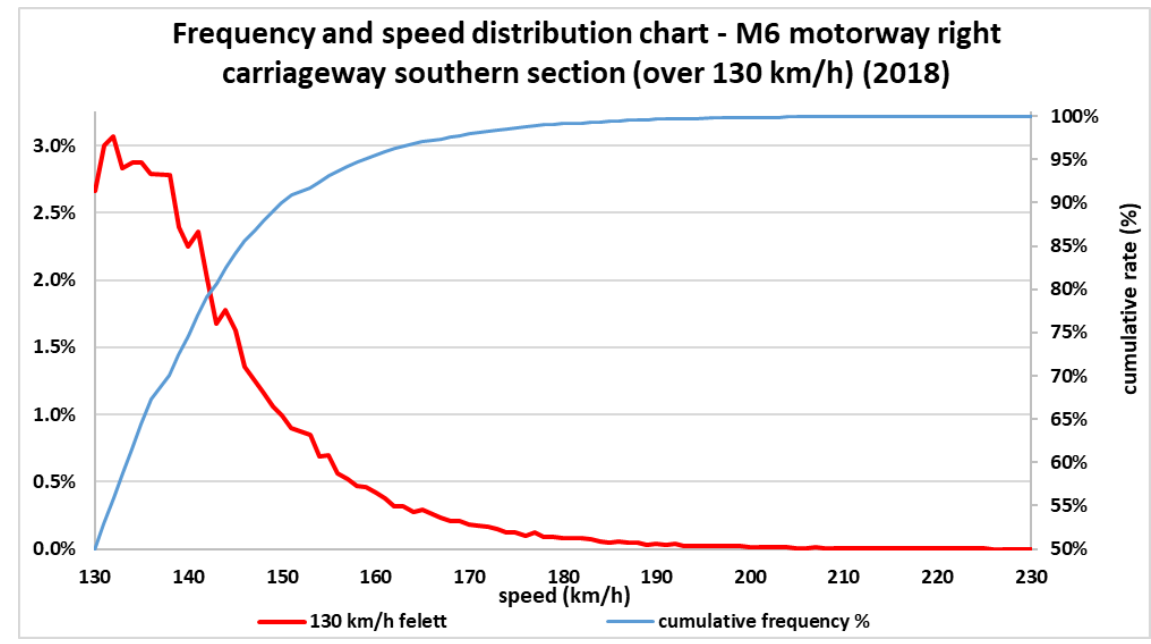

Figure M6-6. Frequency and speed distribution chart - M6 motorway right carriageway southern section (over $130 \mathrm{~km} / \mathrm{h}$ ) (2018) 
Zs. Sándor and Á. Monostori. - Acta Technica Jaurinensis, Vol. 13, No. 3, pp. 211-245, 2020

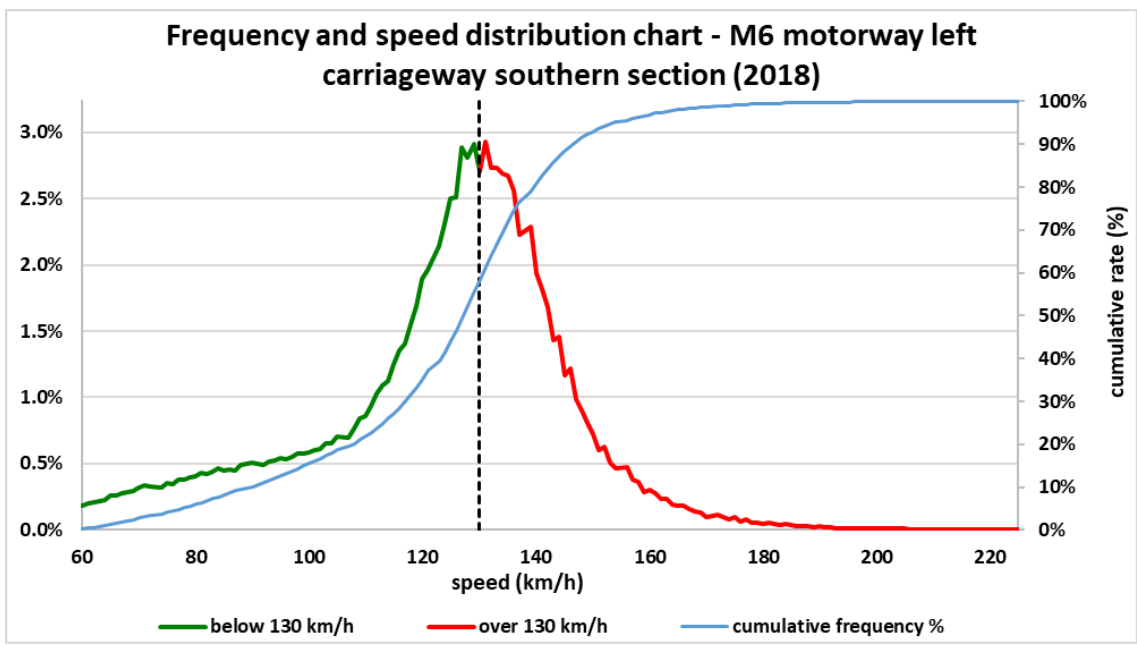

Figure M6-7. Frequency and speed distribution chart - M6 motorway left carriageway southern section (2018)

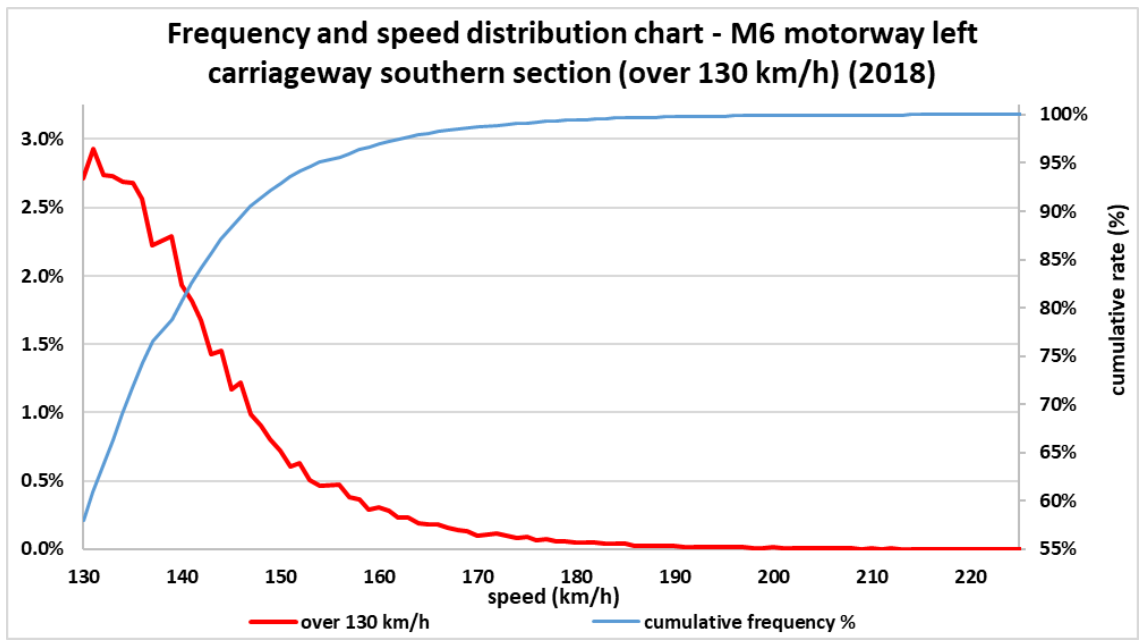

Figure M6-8. Frequency and speed distribution chart - M6 motorway left carriageway southern section (over $130 \mathrm{~km} / \mathrm{h}$ ) (2018) 
Zs. Sándor and Á. Monostori. - Acta Technica Jaurinensis, Vol. 13, No. 3, pp. 211-245, 2020

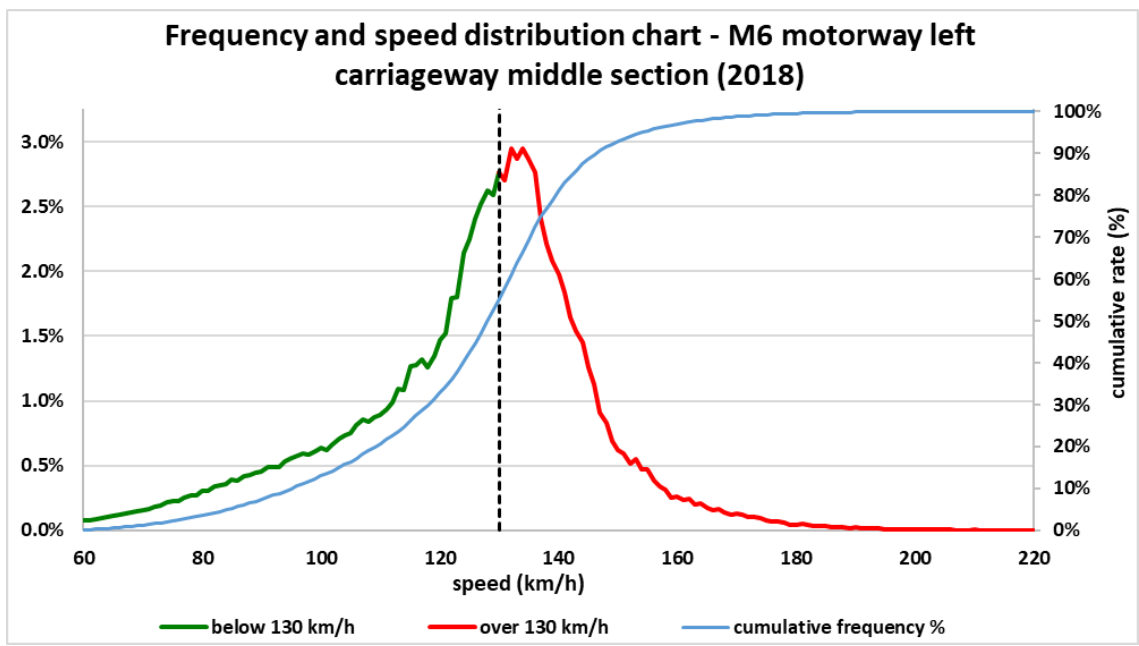

Figure M6-9. Frequency and speed distribution chart - M6 motorway left carriageway middle section (2018)

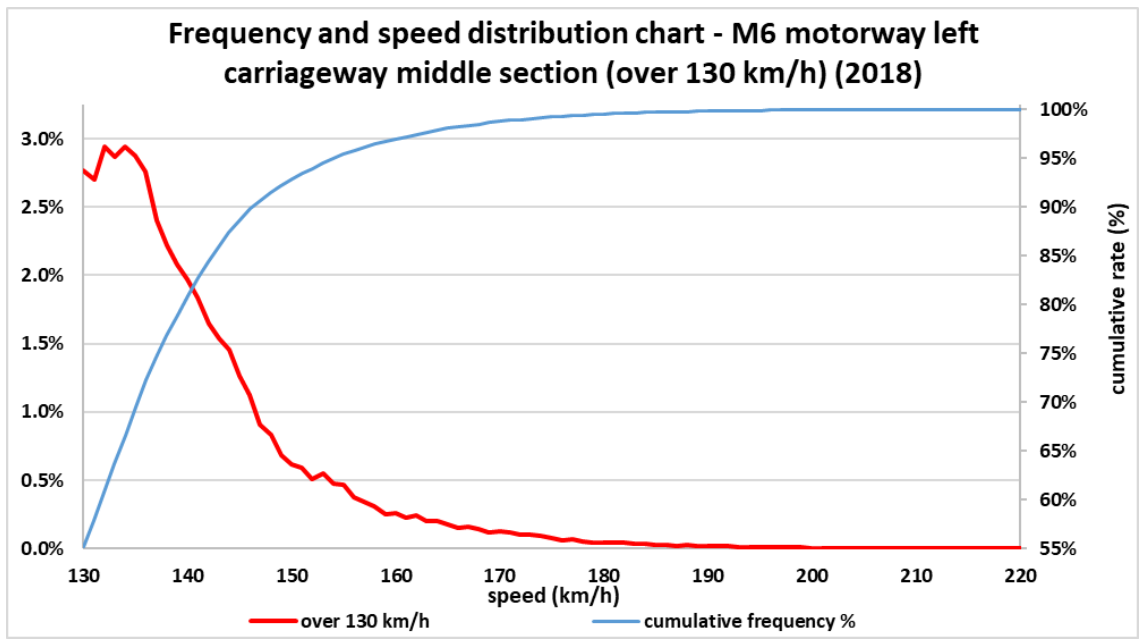

Figure M6-10. Frequency and speed distribution chart - M6 motorway left carriageway middle section (over $130 \mathrm{~km} / \mathrm{h}$ ) (2018) 
Zs. Sándor and Á. Monostori. - Acta Technica Jaurinensis, Vol. 13, No. 3, pp. 211-245, 2020

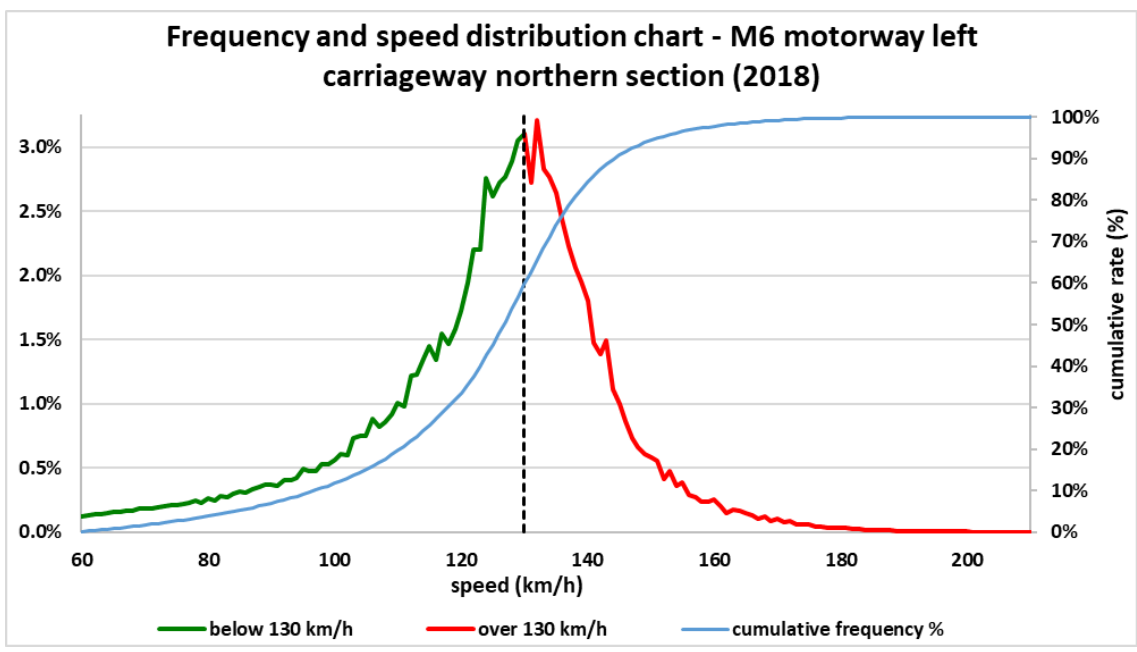

Figure A- M61. Frequency and speed distribution chart - M6 motorway left carriageway northern section (2018)

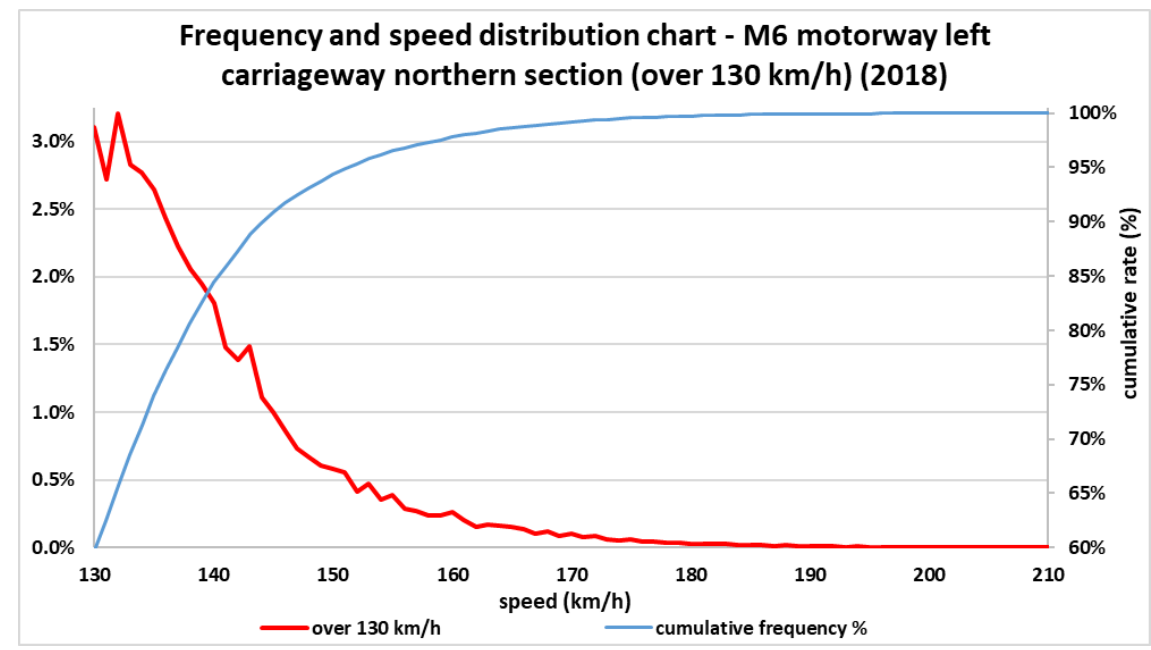

Figure M6-12. Frequency and speed distribution chart - M6 motorway left carriageway northern section (over $130 \mathrm{~km} / \mathrm{h}$ ) (2018) 


\subsection{Supplementary data of M5 motorway sections}

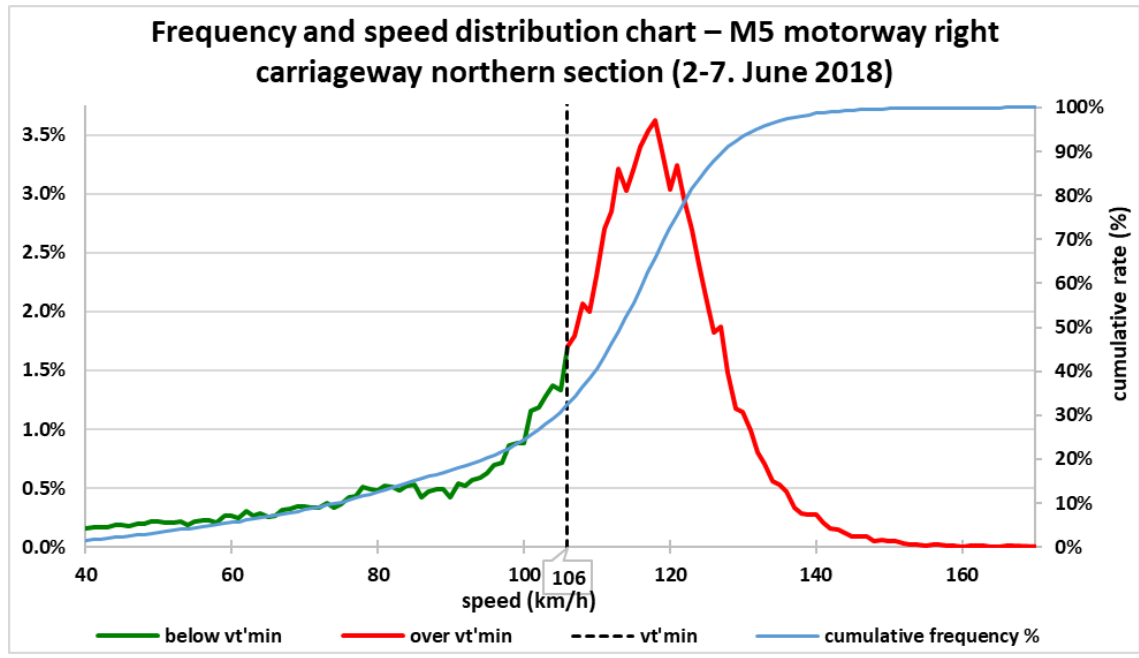

Figure M5-1. Frequency and speed distribution chart - M5 motorway right carriageway northern section (2-7. June 2018)

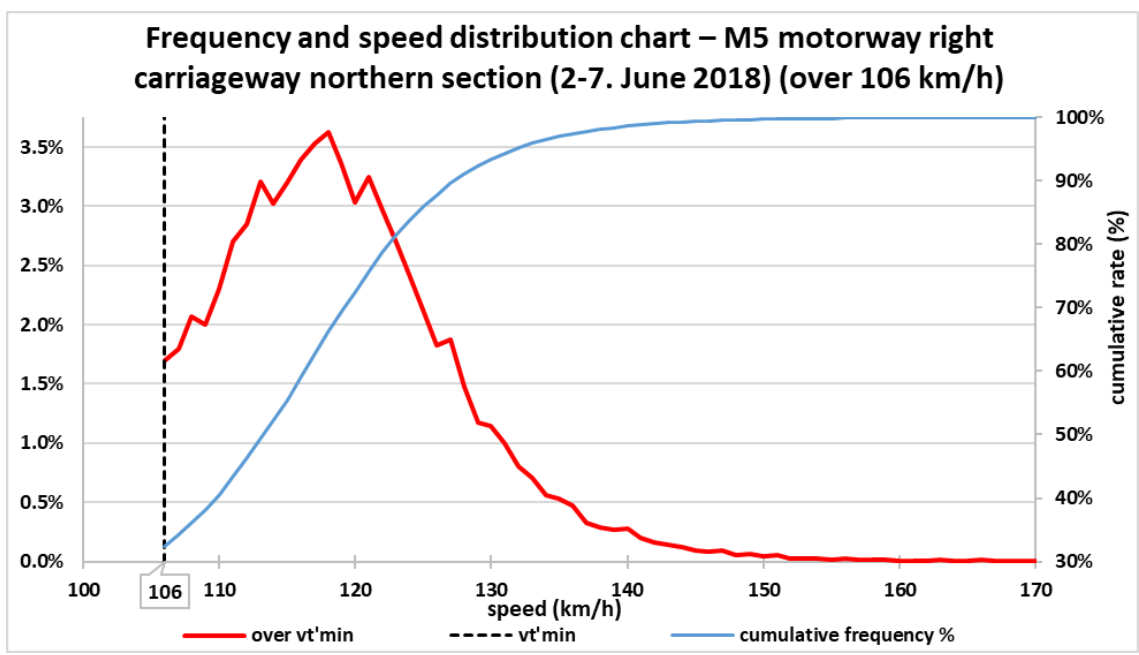

Figure M5-2. Frequency and speed distribution chart - M5 motorway right carriageway northern section (2-7. June 2018) (over $106 \mathrm{~km} / \mathrm{h}$ ) 
Zs. Sándor and Á. Monostori. - Acta Technica Jaurinensis, Vol. 13, No. 3, pp. 211-245, 2020

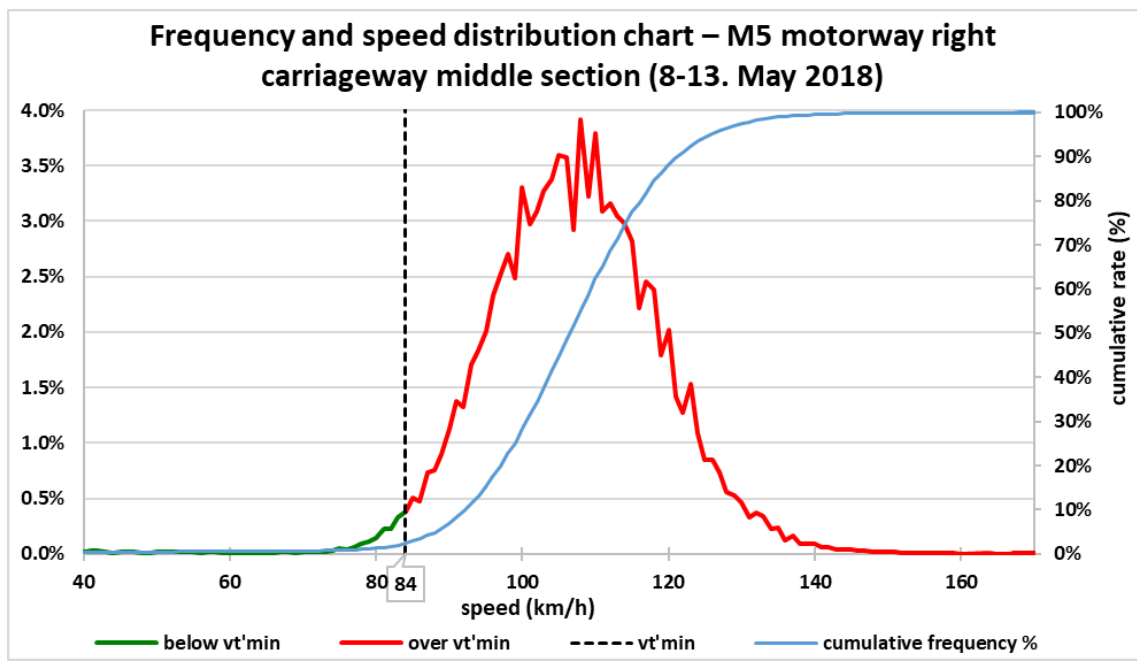

Figure M5-3. Frequency and speed distribution chart - M5 motorway right carriageway middle section (8-13. May 2018)

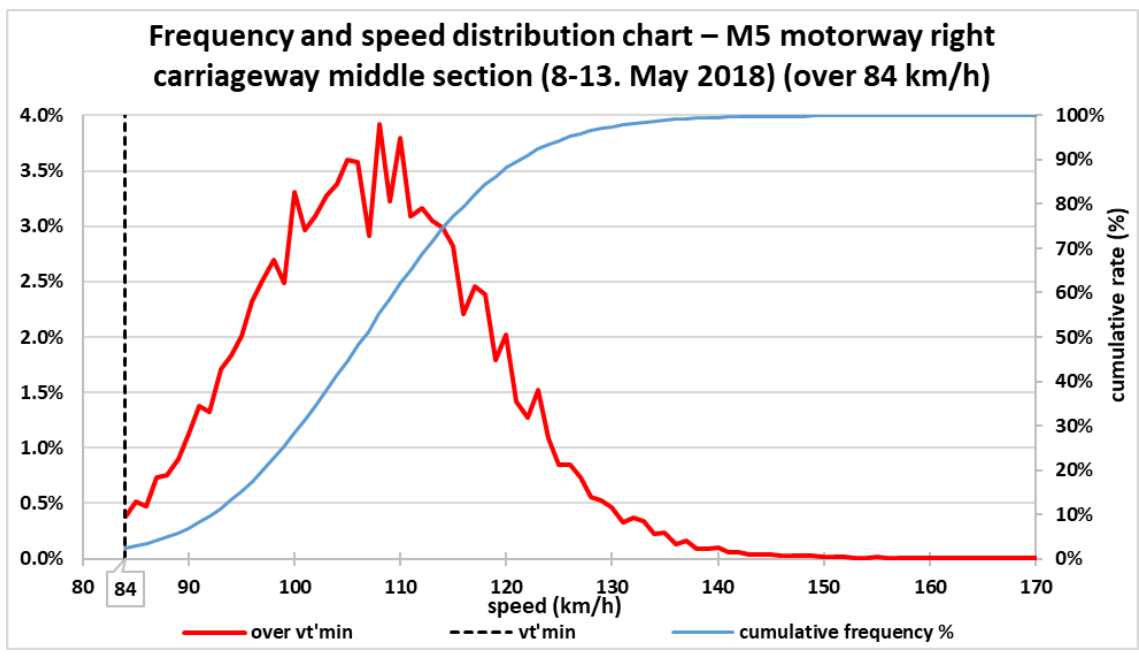

Figure M5-4. Frequency and speed distribution chart - M5 motorway right carriageway middle section (8-13. May 2018) (over $84 \mathrm{~km} / \mathrm{h}$ ) 
Zs. Sándor and Á. Monostori. - Acta Technica Jaurinensis, Vol. 13, No. 3, pp. 211-245, 2020

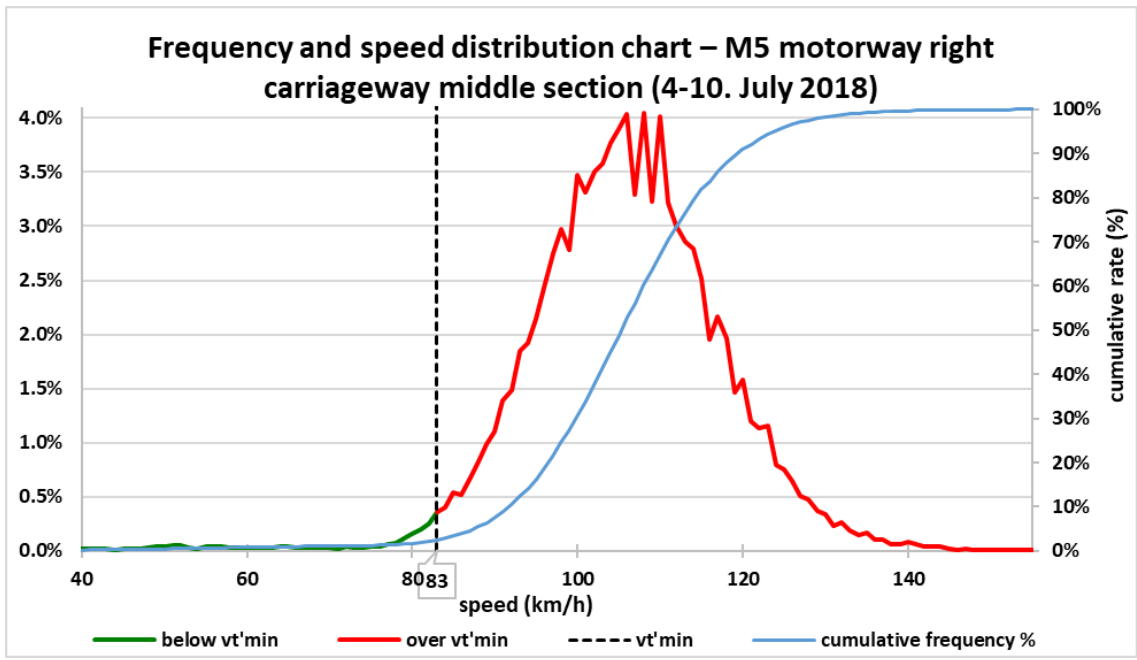

Figure M5-5. Frequency and speed distribution chart - M5 motorway right carriageway middle section (4-10. July 2018)

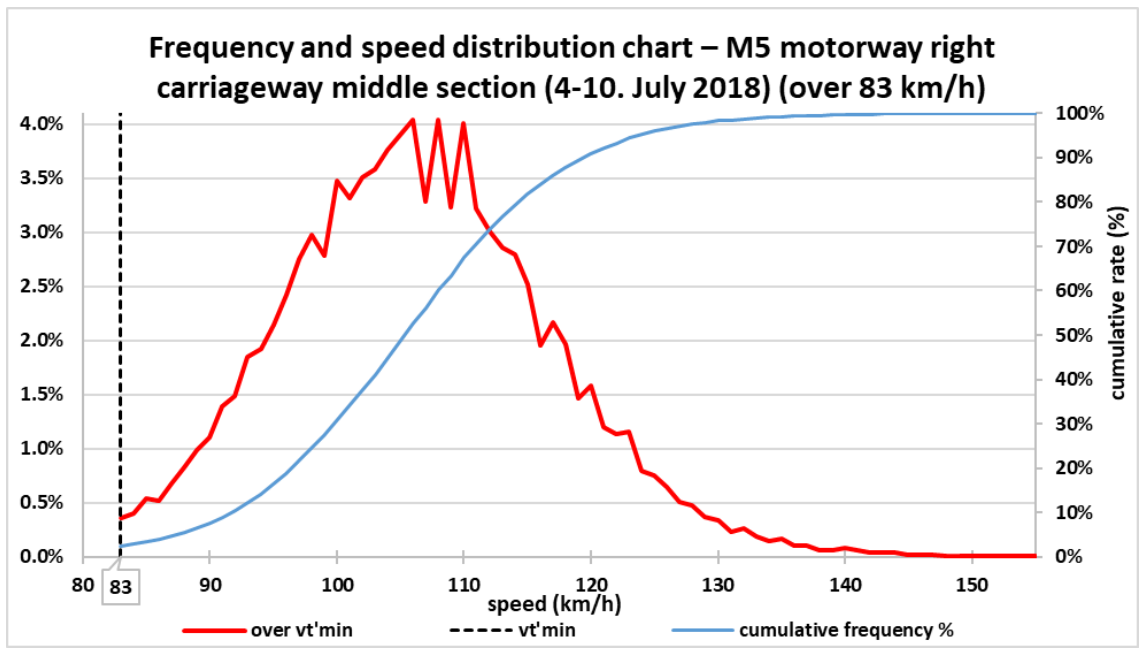

Figure M5-6. Frequency and speed distribution chart - M5 motorway right carriageway middle section (4-10. July 2018) (over $83 \mathrm{~km} / \mathrm{h}$ ) 
Zs. Sándor and Á. Monostori. - Acta Technica Jaurinensis, Vol. 13, No. 3, pp. 211-245, 2020

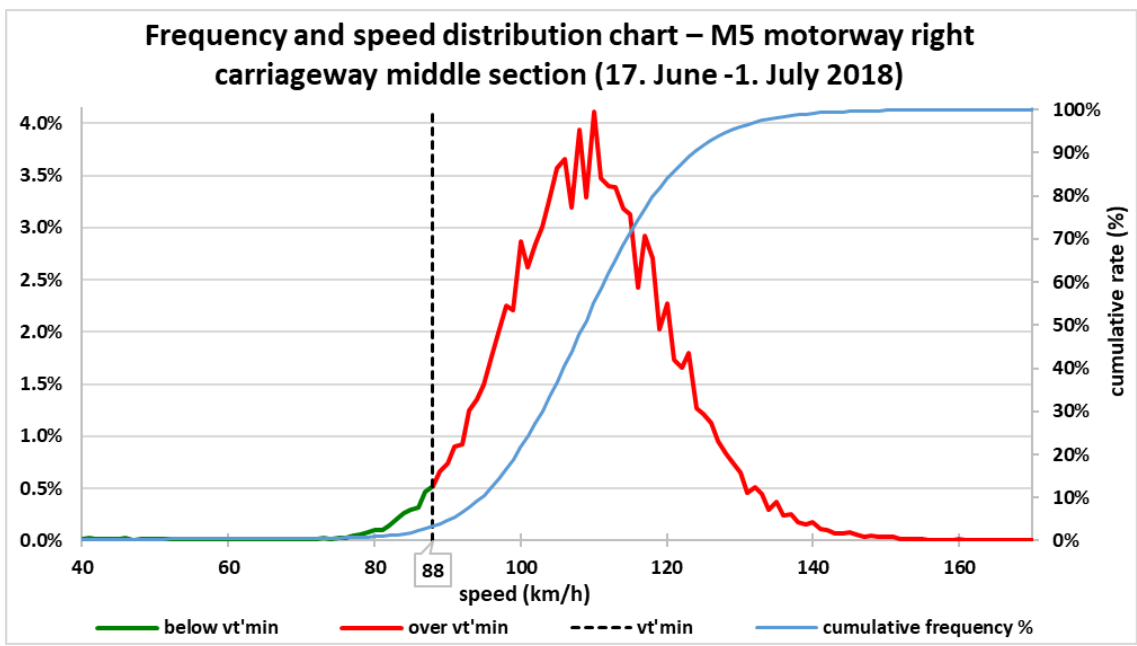

Figure M5-7. Frequency and speed distribution chart - M5 motorway right carriageway middle section (17. June -1. July 2018)

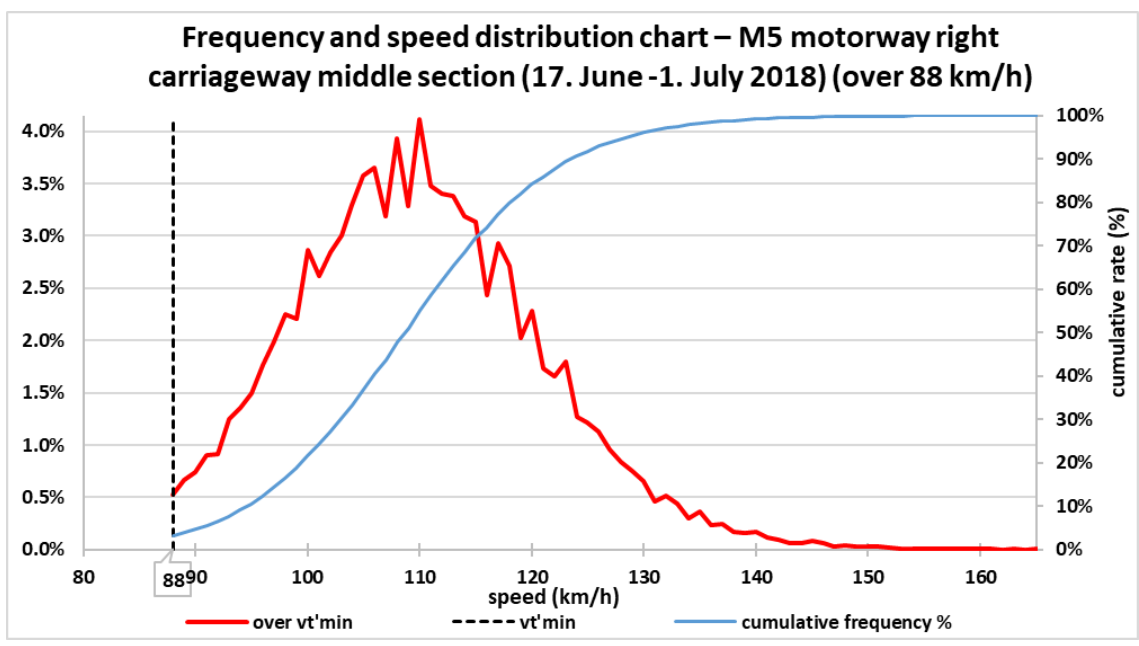

Figure M5-8. Frequency and speed distribution chart - M5 motorway right carriageway middle section (17. June -1. July 2018) (over $88 \mathrm{~km} / \mathrm{h}$ ) 
Zs. Sándor and Á. Monostori. - Acta Technica Jaurinensis, Vol. 13, No. 3, pp. 211-245, 2020

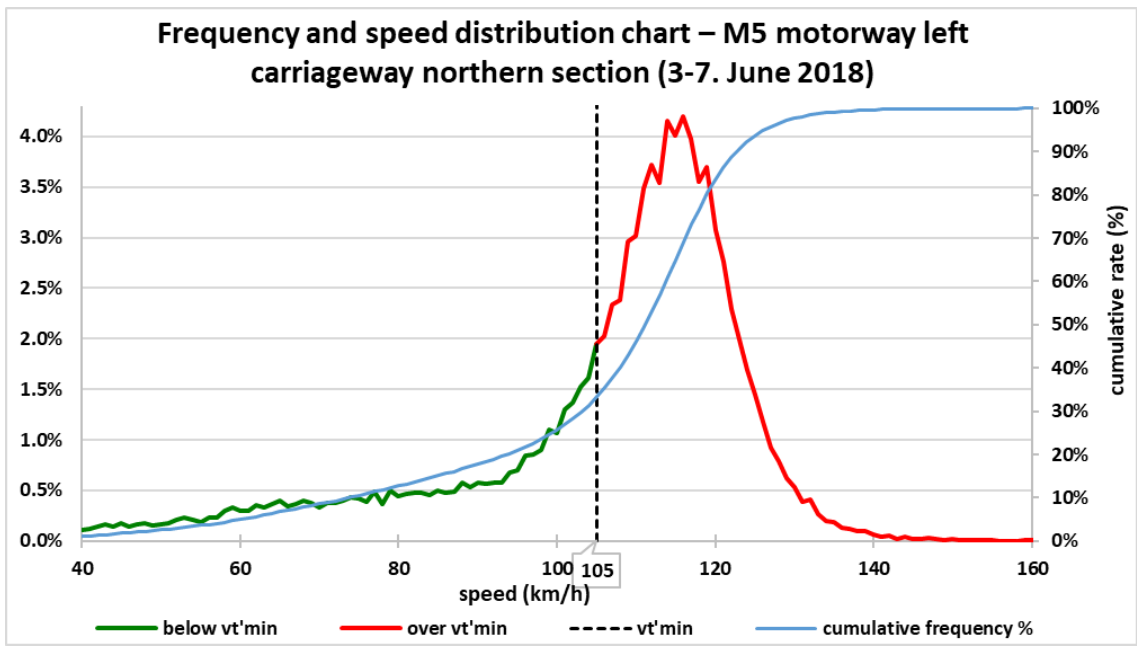

Figure M5-9. Frequency and speed distribution chart - M5 motorway left carriageway northern section (3-7. June 2018)

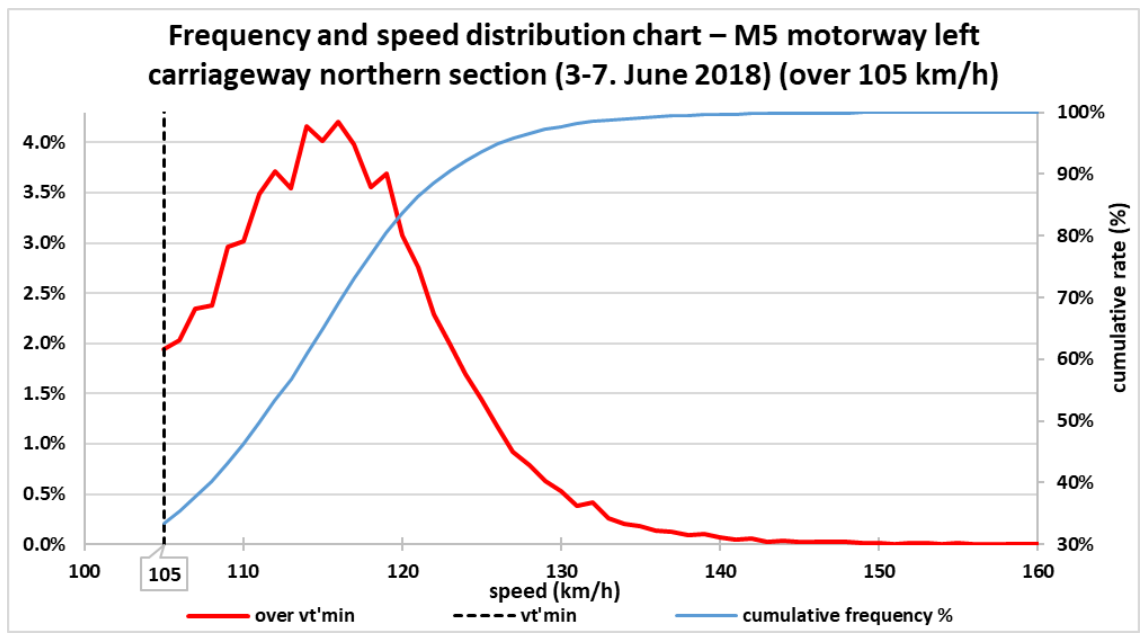

Figure M5-10. Frequency and speed distribution chart - M5 motorway left carriageway northern section (3-7. June 2018) (over 105 km/h) 
Zs. Sándor and Á. Monostori. - Acta Technica Jaurinensis, Vol. 13, No. 3, pp. 211-245, 2020

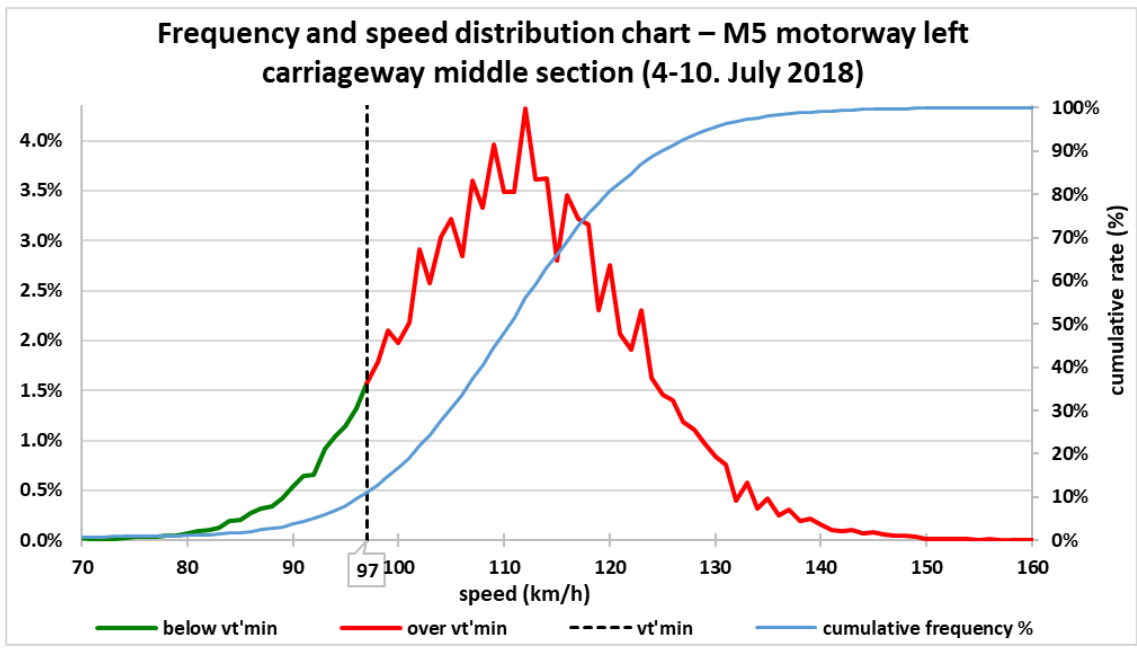

Figure M5-11. Frequency and speed distribution chart - M5 motorway left carriageway middle section (4-10. July 2018)

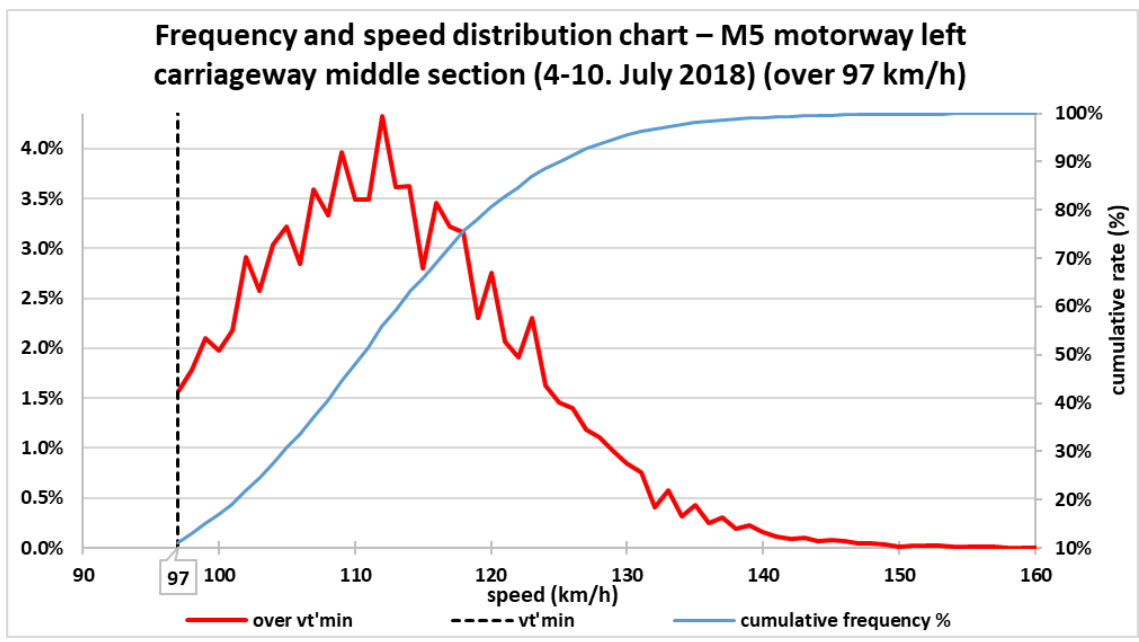

Figure M5-12. Frequency and speed distribution chart - M5 motorway left carriageway middle section (4-10. July 2018) (over $97 \mathrm{~km} / \mathrm{h}$ ) 
Zs. Sándor and Á. Monostori. - Acta Technica Jaurinensis, Vol. 13, No. 3, pp. 211-245, 2020

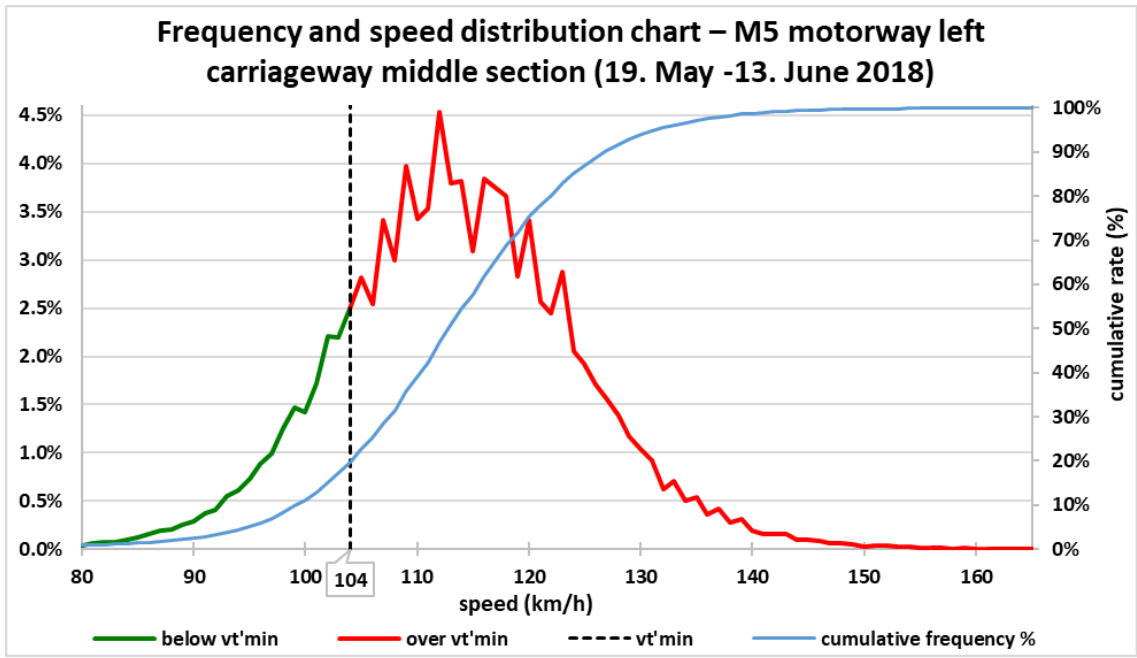

Figure M5-13. Frequency and speed distribution chart - M5 motorway left carriageway middle section (19. May -13. June 2018)

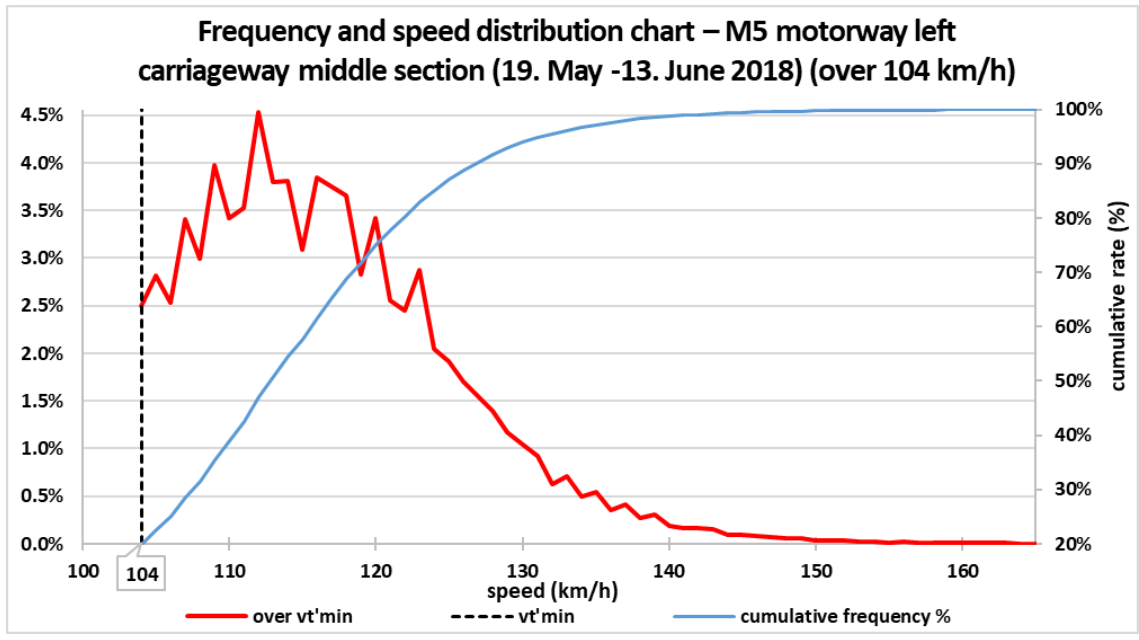

Figure M5-14. Frequency and speed distribution chart - M5 motorway left carriageway middle section (19. May -13. June 2018) (over $104 \mathrm{~km} / \mathrm{h}$ ) 
Zs. Sándor and Á. Monostori. - Acta Technica Jaurinensis, Vol. 13, No. 3, pp. 211-245, 2020

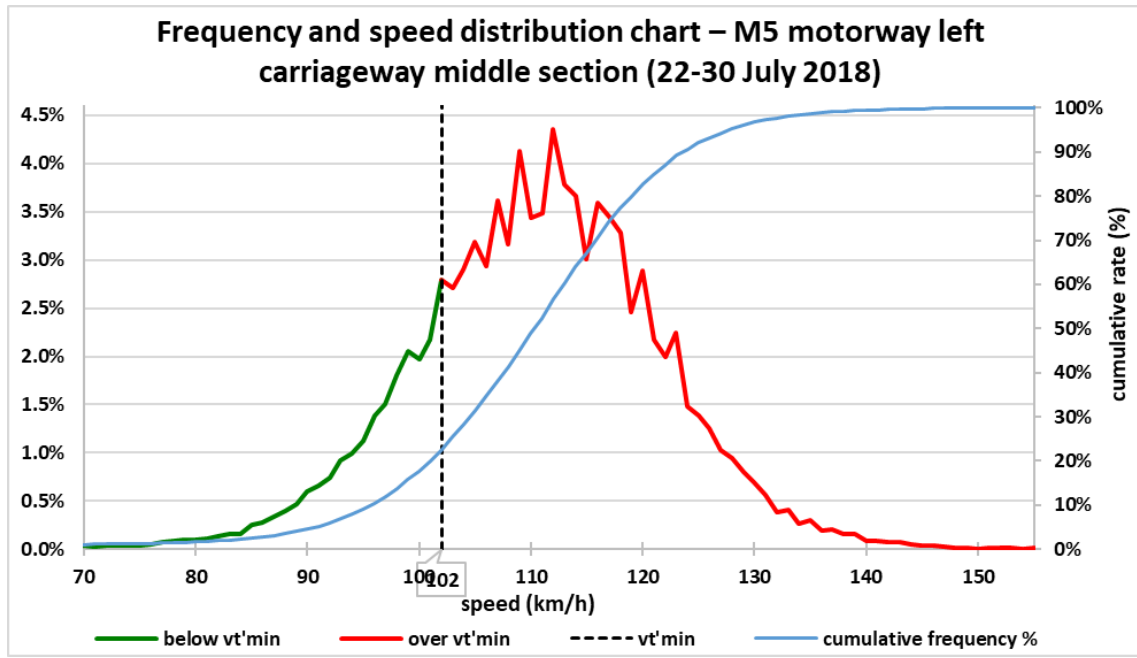

Figure M5-15. Frequency and speed distribution chart - M5 motorway left carriageway middle section (22-30 July 2018)

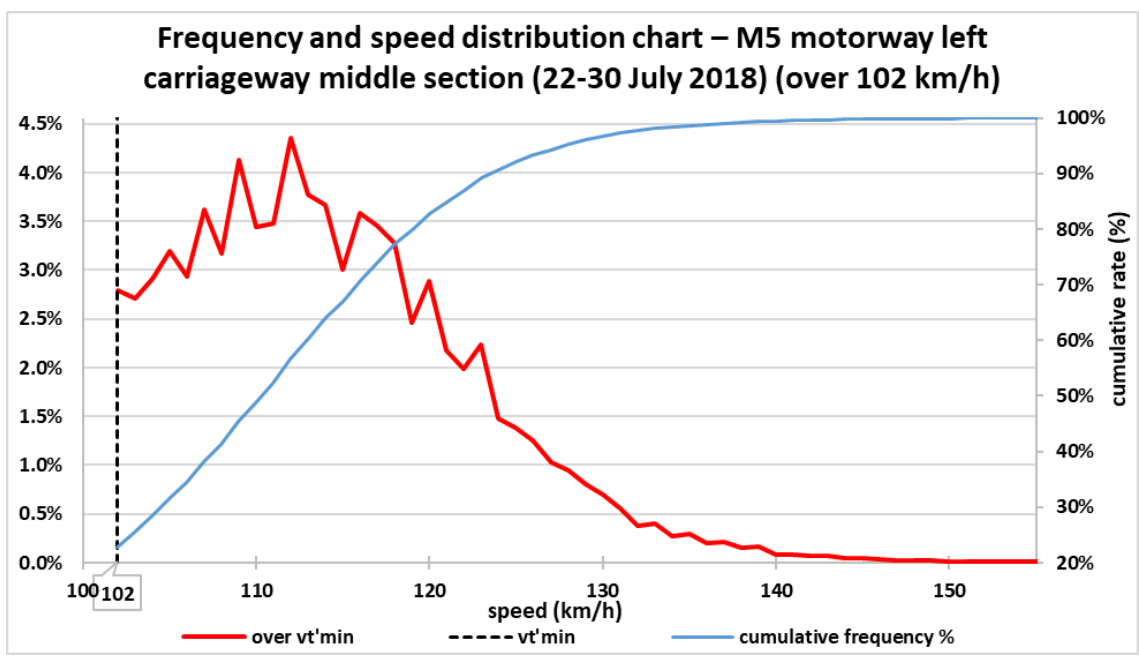

Figure M5-16. Frequency and speed distribution chart - M5 motorway left carriageway middle section (22-30 July 2018) (over $102 \mathrm{~km} / \mathrm{h}$ ) 
Zs. Sándor and Á. Monostori. - Acta Technica Jaurinensis, Vol. 13, No. 3, pp. 211-245, 2020

\section{References}

[1] Hungarian Central Statistical Office, (2019) Official data provision

[2] D.W. Soole, B.C. Watson, J.F. Fleiter, Effects of average speed enforcement on speed compliance and crashes: A review of the literature, Accident Analysis and Prevention 54 (2003) pp. 46-56.

doi: https://doi.org/10.1016/j . aap.2013.01.018

[3] R.E. Allsop, Reducing Traffic Injuries Resulting from Excess and Inappropriate Speed. European Transport Safety Council, Brussels (1995).

[4] A.I. Glendon, Driving violations observed: An Australian study. Ergonomics 50 (8) (2007) pp. 1159-1182.

doi: $h$ ttps ://doi .org/10.1080/00140130701318624

[5] F. Wegman, C. Goldenbeld, Speed management: enforcement and new technologies R-2006-5. Leidschendam, SWOV Institute for Road Safety Research, The Netherlands (2006).

[6] L. Aarts, I.V. Schagen, Driving speed and the risk of road crashes: A review. Accident Analysis and Prevention 38 (2006) pp. 215-224. doi: $h t t p: / / d x$.doi.org/10.1016/j . aap. 2005.07.004

[7] E.W. Korthof, Effects of section control on traffic safety at Dutch motorways, Master thesis, Delft University of Technology, 2014. URL ht tp://resolver . tudelft . nl/uuid:261d7c62-a784-473c98b6-85abe $72 f f d 33$

[8] D. Jankó, L. Csenki, Z. Jákli, G. Magyar, Speeds on motorway M1 and M7 (Sebesség az M1 és az M7 autópályán). Közúti és Mélyépítési Szemle 54 (10) (2004) pp. 11-20. (in Hungarian)

[9] R. Elvik, P. Christensen, A Amundsen, Speed and road accidents: An evaluation of the Power Model (TØI report 740/2004). Institute of Transport Economics. Norway, Oslo (2004). ISBN 82-480-0451-1

[10] J. Malenstein, Automated video speed enforcement and trajectory control, combined with fully automated processing. Intelligent Transport Systems; Towards the new horizon together. Seoul, Korea, 1998.

[11] A. Ragnøy, Automatic section speed control. Results of Evaluation. Norwegian Public Roads Administration, Directorate of Public Roads, Oslo. (2011) ISSN: 1892-3844 
[12] C. Stefan, Section control - automatic speed enforcement in the Kaisermühlen tunnel (Vienna, A22 Motorway). Austrian Road Safety Board (KvF), Vienna, 2006.

[13] A. Montella, B. Persaud, M. D'Apuzzo, L. Imbriani, Safety evaluation of automated section speed enforcement system. Transportation Research Record 2281 (1) (2012) pp. 16-25.

doi: $h$ ttps ://doi.org/10.3141/2281-03

[14] D. Soole, J. Fleiter, B. Watson, Point-to-Point Speed Enforcement (AP-R41512). Austroads, Sydney. (2012) ISBN 978-1-921991-42-4

[15] A.K. Høye, Evaluation of the crash effects of section control. Institute of Transport Economics Norwegian Centre for Transport Research (2014) ISBN 978-82-480-1547-5

[16] P. Johansson, Speed limitation and motorway casualties: a time series count data regression approach. Accident Analysis and Prevention 28 (1996) pp. 7387.

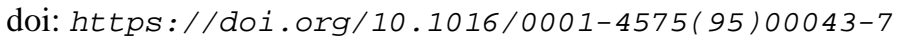

